\title{
MATICES DE TINTA NEGRA Y ALGUNO QUE OTRO COLORINCHE
}

\section{SHADES OF BLACK INK AND ONE OR GAUDY}

Carlos Gamero Esparza: Universidad Inca Garcilaso de la Vega (Perú). carlos.gamero@ozu.es

\section{CURRÍCULUM VITAE}

Reconocido Periodista peruano del Diario OJO de Lima. Licenciado con Diploma de Honor en la Universidad Inca Garcilaso de la Vega.

\section{RESUMEN}

En este texto se muestran una serie de artículos y reportajes publicados en diversas épocas por su autor. Se presentan al azar, sin orden cronológico. Algunos tienen ya tiempo, pero su contenido sigue siendo actual; otros son sabrosos y evocadores, y todos, en suma, marcaron un sentimiento y una emoción irrepetible. Un dossier que tiene a Perú, su mundo y su gente, como protagonista.

\section{PALABRAS CLAVE}

Perú - Gente - Inca - Historia 


\section{ABSTRACT}

In this text are a series of articles and reports published at various times by the author. Occur at random, without chronological order. Some have some time, but its content is still current, others are flavorful and evocative, and all in all, marked a unique feeling and emotion. A dossier that has to Peru, the world and its people, as the protagonist.

\section{KEY WORDS}

Peru - People - Inca - History

\section{ÍNDICE}

\section{Introducción}

2. Parte I. De huacas y dioses

2.1. El verdadero Manco Capac

2.2. Un día muy lejano...

2.3. Una visión milunochesca

2.4. ¡Mallku y no Manco!

2.5. Eclipse, el de los incas

2.5.1. Intimtutayan, cuando se oscurece el Sol...

2.5.2. Inamaqilla

2.6. Paz con concha

2.6.1. Rojo precioso

2.6.2. Los fenicios del Pacífico

2.6.3. Madre de todas las aguas

$$
\text { 2.6.3.1. Pago con sencillo }
$$

3. Parte II. Lugares de por acá (... y de más o menos allá) 
3.1. Perú para todo el mundo

3.2. Yungay

3.2.1. Mudo testimonio: 4 palmeras

3.2.2. 17 años después

3.2.3. ¡No, Yungay no ha muerto!

3.3. Trujillo, la ciudad pintada

3.3.1. Se descubrieron de casualidad

3.3.2. Pinturas por donde sea

3.3.3. Apogeo de la pantorrilla y el copete

3.3.4. Cubrieron los tesoros...

3.3.5. Los apóstoles de las catacumbas

3.4. El alma de los panteones

3.4.1. "Apenas abriste tu párpado tierno..."

3.4.2. Mensajes de esperanza

3.4.3. Frases bíblicas y aforismos

3.4.4. Una anécdota

3.5. Los pájaros vienen a morir al Perú

3.5.1. Aves del Mar de Grau

3.6. Recuerdos del Vaticano

3.7. Carsi: Encuentro con la casa familiar

4. Parte III. Ingas y mandingas

4.1. Abimael, el griego

4.2. ¡Qué buena promo...!

4.2.1. José María Salcedo: "Blancas iba a ser político desde chiquito, pero jamás hubiera previsto el futuro de Mezzich"

4.3. Miguel Hitotsuishi: Balada para un gentil hombre...

\subsubsection{Semblanzas...}

5. Notas Aclaratorias

6. Referencias y fuentes 
7. Procedencia de las imágenes

\section{TEXTO:}

\section{Introducción}

Buscar entre los viejos recortes de mi devenir periodístico fue como penetrar en el túnel del tiempo, y ahora más que nunca, para recordar los 18 difíciles pero maravillosos años en que este servidor transitó por los diarios OJO y Correo de Lima; años, días y meses de sueños, ensueños y pesadillas, con vivencias tan salpicadas de experiencias que ahora queremos compartir con nuestros lectores. Esta es una selección de artículos y reportajes publicados en diversas épocas, presentados al azar, sin orden cronológico. Algunos tienen ya tiempo, pero su contenido sigue siendo tan actual; otros son tan sabrosos y evocadores, y todos, en suma, marcaron un sentimiento y una emoción irrepetible. Un "dossier" que tiene al Perú y su mundo y su gente por protagonista. Os invitamos a entrar en el mundo variopinto de los...

(Nota: Aunque se ha respetado la redacción original de estos trabajos, que aparecen tal como fueron publicados, advertimos al amable lector que en el presente trabajo hay puntuaciones y palabras que han sido "recicladas" -dada la antigüedad de estos trabajos periodísticos-, actualizadas o cambiadas, con aclaraciones y puntualizaciones de algunas palabras o frases que podrían inducir a duda o confusión, todo ello en un afán del autor por corregir fallos circunstanciales; aún así, como podrá apreciarse, el contenido es básicamente el mismo, respetándose el fondo y la forma: la remembranza de una evolución periodística, la misma que hemos puesto como Dios manda, de forma aleatoria, para darle más variedad...) 


\section{Parte I. De huacas y dioses}

\subsection{El verdadero Manco Capac}

(Artículo publicado en el Suplemento Dominical del diario OJO, el domingo 7 de junio de 1987, pp. 6)

El Titicaca en su inmensidad azul ha sido, desde siempre, escenario de historias y leyendas que se pierden en la noche de los tiempos. Y entre estos relatos hay uno que guarda especial significado para los habitantes del Collao (Nota 1), y que es evocada cada año como una manifestación viviente del origen ancestral de los incas: la leyenda de Manco Capac, el que vino del este... He aquí el relato que tal vez muchos de los lectores hayan escuchado, pero que posee un simbolismo mítico que hay que desentrañar...

\subsection{Un día muy lejano...}

Así fue cómo surgió la estirpe de pumas y cóndores, los hijos del Sol y la Luna, adoradores de la Mamapacha (Nota 2). "Un día muy lejano, el Sol, al ver que los hombres vivían como animales, tuvo piedad de ellos y tanta lástima, que les envió uno de sus hijos y una hija para que dieran a estos bárbaros el conocimiento de las leyes y pudieran vivir como hombres de razón, en casas y lugares donde gozarían de los frutos de la tierra." (1)

La leyenda continúa diciendo: "El Sol depositó a sus hijos en la Isla de Titicaca (Nota 3) ordenándoles que enseñaran a los bárbaros que le adoraran como Dios... Les dio un bastón de oro de un grosor de dos dedos. En todas partes donde se detendrían, deberían hundirlo en tierra hasta que desapareciera, marcando el lugar escogido por su Padre-Sol para fundar un imperio." (1) 
Desde entonces, esta leyenda es evocada con representaciones folklóricas por los habitantes de la meseta del Collao (Nota 1), especialmente en las zonas ribereñas... es un verdadero acontecimiento social que atrae a miles de visitantes.

En Puno (Nota 4) (19) se representa la llegada del hijo del Sol. Dejemos que Simone Waisbard (2) nos relate una experiencia que ella tuvo oportunidad de vivir... "Al caer la noche del 3 de noviembre, amontonados en camiones y en balsas de caña llegan miles de indios vestidos con sus trajes tradicionales, para escoger a Manco Capac y a Mama Ocllo, sus legendarios antepasados incas.

No es sólo una imagen, una reconstrucción histórica que dejaría traslucir su alma india pura. Inocentemente los aymaras (Nota 5) del lago Titicaca (Nota 6) creen en el regreso de los equivalentes incas de Adán y Eva.

Pero al revés que cualquier manifestación folklórica y popular del mundo, ningún murmullo agita la puerta de Puno (Nota 4) en la que esperan, sin impaciencia, la fabulosa aparición. Excepto por las ráfagas de musiquilla acidulada de las zampoñas, flautas de pan indias, de bambú, acompañadas del ulular en tres notas agudas y penetrantes de las quenas de hueso de llama, y el ritmo del golpe sordo de los tambores, las voces humanas callan. Esta cantinela obsesionante, embrujadora ¿no es acaso la voz de los siglos?

La coca anestesia la mirada de los hombres con ponchos. (...) En estos trópicos helados, toda la noche, sesenta mil personas ¡esperan el retorno de los incas! (1) 


\subsection{Una visión milunochesca}

El espectáculo increíble de las Mil y Una Noches indias es ahogado por los copos de nieve y al llegar la aurora, a la orilla de un lago nacarado, el termómetro marca un poco menos de los 10 grados.

La leyenda cuenta que después del Diluvio andino, el Sol lanzó su primer rayo de luz al lago Titicaca. Y en el dedo del Sol naciente, creció repentinamente la pintoresca y silenciosa armada de centenares de balsas de totora (Nota 7) (20) de cañas secas como el oro, atadas formando grandes canoas fusiformes con la popa y la proa levantadas como la punta de un zueco.

El viento del lago infla las velas altas de los juncos. En la parte delantera un navegante aborigen con poncho rojo va de pie, con una pértiga larga en la mano para guiar la embarcación. Agachada atrás, su compañera hila lana de llama en un huso de madera. A veces, incluso una llama les escolta a bordo, con una lana rosa vivo en cada oreja.

Manco Capac y Mama Ocllo vienen del Este, de la Isla del Sol, en el corazón del lago sagrado, fieles a la tradición. En el embarcadero, mudos, inmutables como sonámbulos, los indios contemplan los grandes personajes de su génesis tocados con corona de oro emplumado; un disco solar de oro resplandece en su pecho. ¡Por fin llegaron los semidioses!" (1) 


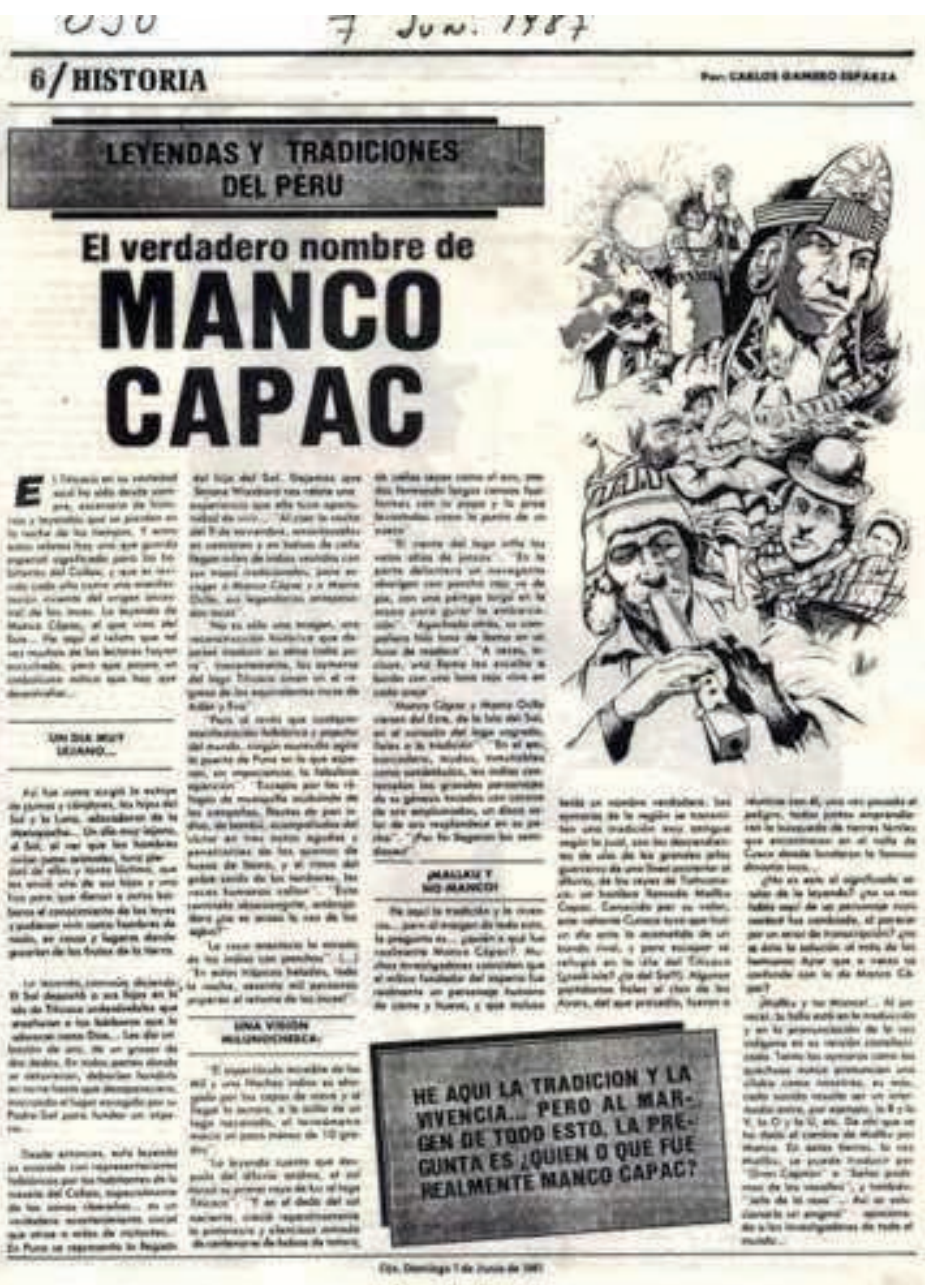

Figura 1. Recorte de "El verdadero Manco Capac".

\section{4. ¡Mallku y no Manco!}

He aquí la tradición y la vivencia... pero, al margen de todo esto, la pregunta es... ¿quién o qué fue realmente Manco Capac? Muchos investigadores coinciden que el mítico fundador del imperio fue realmente un personaje humano de carne y hueso, y que incluso tenía un nombre verdadero. Los aymaras de la región se transmiten una tradición muy antigua según la cual, son los descendientes de uno de los grandes jefes guerreros de una línea posterior al diluvio, un hombre llamado Mallku Capac Conocido por su valor, este valiente Curaca tuvo que huir un día ante la acometida de un bando rival, y para escapar se refugió en la isla del Titicaca (¿cuál isla? ¿la del 
Sol?) Algunos partidarios fieles al clan de los Ayars, del que procedía, fueron a reunirse con él; una vez pasado el peligro, todos juntos emprendieron la búsqueda de tierras fértiles que encontraron el valle de Cusco donde fundaron la famosa dinastía inca...

¿No es esto el significado secular de la leyenda? ¿No se nos habla aquí de un personaje cuyo nombre fue cambiado, al parecer por un error de transcripción? ¿No es ésta la solución al mito de los hermanos Ayar (Nota 8) que a veces se confunde con la de Manco Capac?

¡Mallku y no Manco!... Al parecer, la falta está en la traducción y en la pronunciación de la voz indígena en su versión castellana. Tanto los aymaras como los quechuas nunca pronuncian una sílaba como nosotros, es más, cada sonido resulta ser un intermedio entre, por ejemplo, la B y la V, la O y la U, etc. De ahí que se ha dado el cambio de Mallku por Manco. En estas tierras, la voz Mallku (Nota 9) se puede traducir por "Gran Capitán" o "Señor poderoso de los vasallos", y también "Jefe de la raza"... Así se soluciona un enigma que ha apasionado a los investigadores de todo el mundo.

\subsection{Eclipse, el de los incas}

(Artículo publicado en el Suplemento Dominical del diario OJO, el domingo 07 de agosto de 1994, pp. 10)

Será el último eclipse total del siglo. Cubrirá el día por unos minutos en medio país (Nota 10). Pero ¿cómo reaccionaban en la antigüedad incaica ante sucesos de esta naturaleza. Lea esta nota... 
Lo habían predicho los sacerdotes. De pronto la sombría oscuridad se extendió al mediodía sobre el valle del Cusco (Nota 11). Los animales silvestres huyeron a sus escondrijos, las flores cerraron sus pétalos y los perros aullaron lastimeramente. Los hombres del campo, asombrados por el fenómeno celeste, dejaron sus instrumentos de labranza y dirigieron su aterrada mirada al cielo. Todos vieron como el Inti, el dios Sol (Nota 12), era prácticamente devorado por las fauces de la negrura... ¡Es la gran serpiente del cielo que se come al dios Inti! -decían unos - „Es Viracocha! decían otros (Nota 13) - . El radiante disco solar terminó por desaparecer. La "noche en pleno día" duró largos minutos. Después, un resplandor anunciaba que "volvía el día." Los sacerdotes del Coricancha (Nota 14) sacrificaron un tropel de llamas en la plaza Huacaipata (Nota 15), mientras hombres y mujeres se golpeaban el pecho, se arrancaban los cabellos y gritaban de dolor, clamando al cielo el retorno del Sol.

Y no está de más este relato ficción que, dicho sea de paso, se trata de algo que pudo haber sucedido en el antiguo Perú, y no una sino muchas veces, como lo atestiguan viejas leyendas y tradiciones recogidas en el siglo XVI por los cronistas de la Conquista, y los admirables conocimientos astronómicos de estas gentes que supieron edificar intihuatanas (Nota 16) para "amarrar" al Inti y predecir tanto los eclipses solares como lunares, además de otros fenómenos del cielo.

Entre los habitantes del antiguo Perú -y del mundo, pues en nada tuvieron que envidiar a culturas como la Sumeria o la China- este fenómeno era un acontecimiento de hondas repercusiones religiosas, económicas, sociales, y hasta políticas (Nota 17). Para la supersticiosa mentalidad andina se trataba ciertamente de la "muerte" del Sol. El oscurecimiento del astro rey, funesto a los mortales, que naturalmente era seguido por el retorno triunfante de la luz, recibido, desde luego, con alivio y alborozo por los temerosos hijos de la Tierra. 


\subsubsection{Intimtutayan, cuando se oscurece el Sol...}

Desde tiempo inmemorial, los eclipses de Sol y de Luna siempre fueron motivo del mismo y atávico espanto, y más aún, cuando en ese entonces no eran precisamente científicos quienes se interesaban por estos fenómenos. Eran unos pocos iniciados en las ciencias del firmamento que usaban el poder de su conocimiento para dominar a una plebe ignorante y temerosa de la cólera de los dioses. Y los controlaban, pues ellos eran los únicos que sabían cuándo sembrar la tierra, cuándo festejar el solsticio de invierno o Inti Raymi (Nota 18), cuándo sucedían los equinoccios, cuándo celebrar los sacrificios para aplacar las iras divinas... y cuándo las fauces de la terrible Amaru, la gran serpiente celeste (Nota 19), iban a devorar al Sol... o a la Luna, según sea el caso.

En el estudio del Hanan Pacha -el cielo de la cosmología incaica - los eclipses, tanto de Sol como de Luna, ocuparon un lugar preponderante en la vida cotidiana de los incas. El eclipse total de Sol era conocido como Intimtutayan. Cuando se trataba del parcial, recibía la denominación de Yantuytucunasillan. Por su parte, al eclipse lunar le decían Quillaptutayaynin, siendo Qilla la Luna llena, Qillahuaño, la menguante y Quillapuna la creciente. 


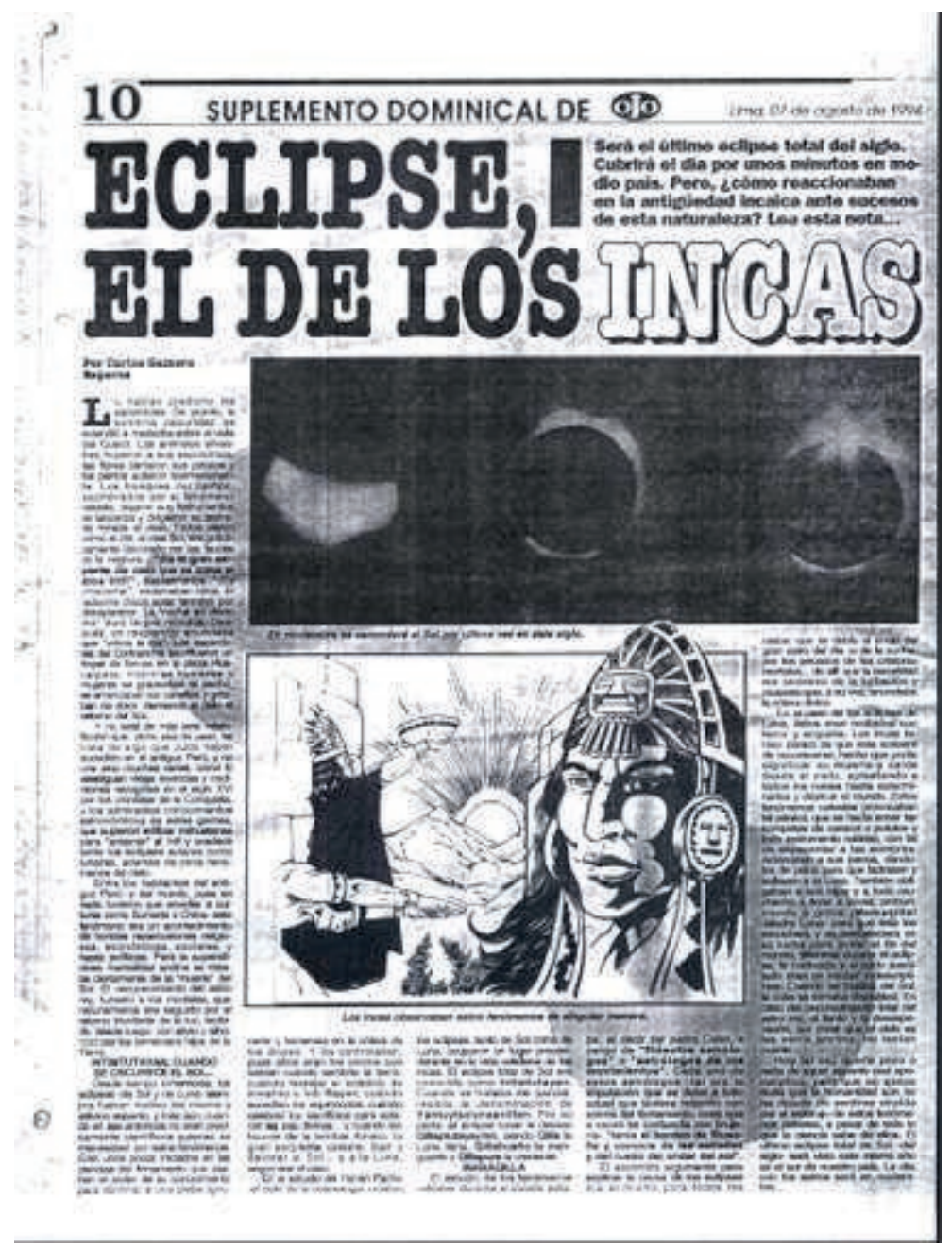

Figura 2. Recorte de "Eclipse, el de los incas".

\subsubsection{Inamaqilla}

El estudio de los fenómenos celestes durante el incario estaba, al decir del padre Cobo (Nota 20), a cargo de filósofos astrólogos o astrólogos de los movimientos. Cada uno de estos astrólogos - tal era la imputación que se daba a todo aquel que tuviera relación con astros del firmamento, cosa que a veces se confundía con brujería - tenía el orden de filosofía y conocía de las estrellas y del ruedo del andar del sol. (3) 
El socorrido argumento para explicar el origen de los eclipses era el mismo para todos los casos: que se debía al enojo del gran astro del día -o de la noche - por los pecados de las criaturas mortales... de allí que la oscuridad era sinónimo de la turbación y molestia que, a su vez, anunciaba la cólera divina.

En el caso de los eclipses de Luna, estos eran recibidos con terror y angustia. Los incas tenían pánico de que ésta acabara de oscurecerse, hecho que podía significar su muerte y caída desde el cielo, aplastando a todos los runas (Nota 21) hasta exterminarlos y destruir el mundo. Estos fenómenos celestes provocaban tal pavor, que se hacía sonar las trompetas de caracol o pututos (Nota 22) y todo instrumento ruidoso, con tal de aspaventar a las sombras. Amarraban a sus perros, dándoles de palos para que ladrasen y aullasen a la Luna. También obligaban a sus hijos y a todo muchacho a llorar a voces, pronunciando a gritos ¡Mamaqilla! -Madre Luna - para que ésta los escuchara y no desfalleciera en su lucha para evitar el fin del mundo. Mientras duraba el eclipse, la confusión y el ruido suscitado eran en verdad indescriptibles. Cuando se trataba del Sol, la cosa se tornaba dramática. En caso del oscurecimiento total del astro rey, el llanto y la desesperación, por creer que el cielo se les venía encima, no tenían cuento...

Hoy tal vez quede poco o nada de aquel espanto casi apocalíptico, pero que no quepa duda que la humanidad no ha dejado de sentirse atraída por el embrujo de estos fenómenos celestes, a pesar de todo lo que la ciencia sabe de ellos. El último eclipse total de Sol -del siglo - (Nota 10) será visto este mismo año en el sur de nuestro país. La cita con los astros será en noviembre.

El rojo sortilegio del Spondylus, o mullu, curioso símbolo de la pacificación de la frontera norte. 


\subsection{Paz con concha}

(Reportaje publicado en el Suplemento Dominical de OJO, el domingo 23 de mayo de 1999, pp. 10 - 11)

Pocos materiales eran tan valorados en la época preincaica como esta suerte de molusco sagrado que recibía el nombre de mullu o chaquira. Se les consideraba piedras preciosas, superiores a las perlas que se extraían de los fondos marinos de Tumbes y Huancavilca (Nota 23), y su estudio ha venido a rescatar los antiguos lazos entre los pueblos de Ecuador y Perú, que, por otra parte, acaban de sellar su demarcación fronteriza.

En muchas tumbas del antiguo Perú, una de las principales ofrendas que acompañaban a los muertos ilustres o simples vasallos era una hermosa concha roja, una valva que colgaba de su cuello, mismo amuleto mítico-sacro, o chaquiras de mil piezas llamadas mullu (Nota 24). La concha mágica, omnipresente y eterna.

El mullu es la caracola marina fragmentada en pedazos y utilizada para fabricar las famosas chaquiras, además de ajorcas y collares. Son moluscos propios de los mares tropicales y subtropicales de América. De las tres especies conocidas, la más valorada era la Spondylus princeps, que habita desde la Baja California, en México, hasta La Puntilla, en Santa Elena, Ecuador. De estos, la caracola de los sueños míticos fue la Spondylus princeps.

Para los pescadores tumbesinos simbolizaba el agua y la lluvia. Por él supieron de la existencia de la Corriente del Niño (Nota 25). Cuando éste se aparece en las playas, tiemblan, pues no sólo significa escasez de pescado sino también desastre para la agricultura. Desde tiempo inmemorial sabían que este molusco era su mejor indicador meteorológico. Su ausencia en las cálidas aguas del norte es claro síntoma 
de coyuntura climática adversa, entonces saben que con seguridad será un año de sequía.

\subsubsection{Rojo precioso}

Los sacerdotes de Pachacamac (Nota 26) esperaban con ansiedad los cargamentos de Spondylus y mullu, utilizados como ofrenda para sus dioses. Spondylus era sinónimo de buen año para los cultivos. Su historia se pierde en la bruma del tiempo. En la llamada "huaca de los sacrificios", ubicada en el "centro ceremonial" de Aspero (4), uno de los sitios arqueológicos más antiguos de la costa peruana, el arqueólogo norteamericano Robert A. Feldman descubrió en 1974 el entierro de un niño que llevaba entre su ajuar funerario piezas hechas de Spondylus, que fue datado en 2,300 antes de Cristo.

En otro sitio arqueológico, La Galgada (5), en el río Tablachaca, un afluente del Santa, los arqueólogos Terence Grieder, de la Universidad de Texas (6), y Alberto Bueno, de la Universidad de San Marcos (7), excavaron la cima de una de sus pirámides, la mayor de ellas, para descubrir unos cuartos donde, al parecer, se desarrollaba un tipo de culto. En este centro ceremonial de unos 4,500 años de antigüedad, aparecieron hermosos objetos tallados, engastados en mullu. 


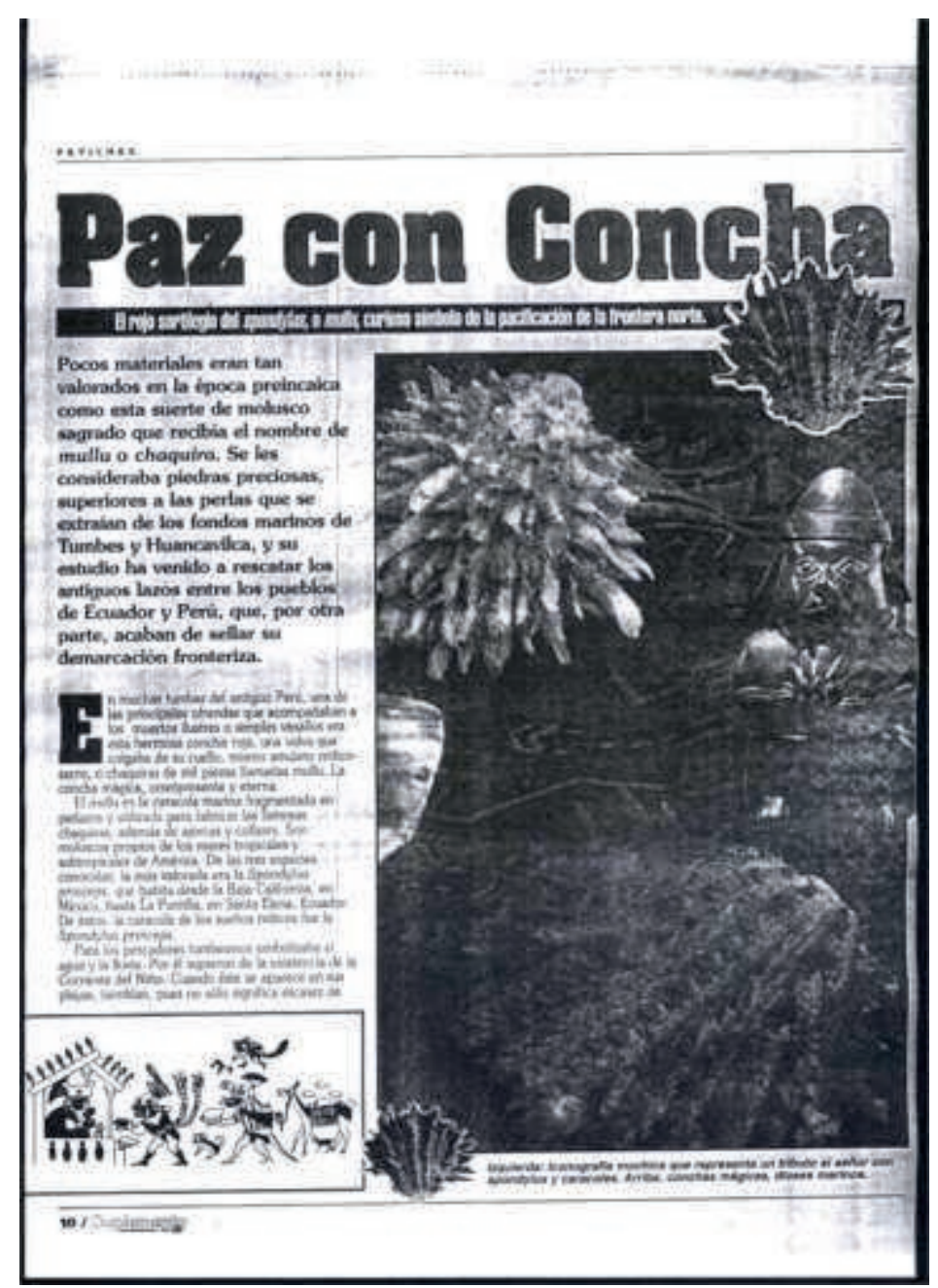




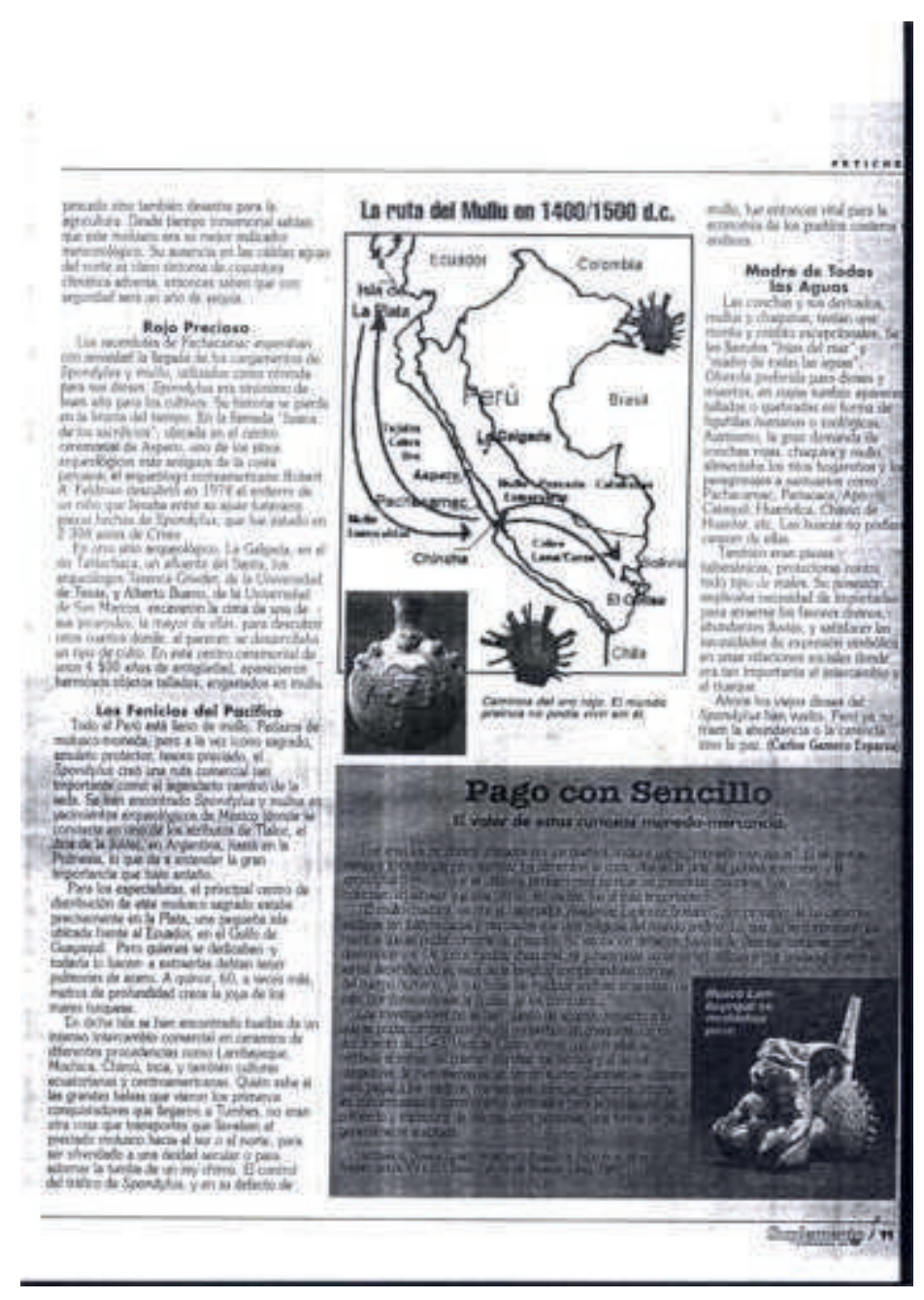

Figuras 3a. y 3b. Recortes de "Paz con concha".

\subsubsection{Los fenicios del Pacífico}

Todo el Perú está lleno de mullu. Pedazos de molusco-moneda, pero a la vez icono sagrado, amuleto protector, tesoro preciado, el Spondylus creó una ruta comercial tan importante como el legendario camino de la seda. Se han encontrado Spondylus y mullus en yacimientos arqueológicos de México (donde se convierte en uno de los atributos de Tlaloc, el dios de la lluvia) (8) (Nota 27), en Argentina, hasta en la Polinesia, lo que da a entender la gran importancia que tuvo antaño. 
Para los especialistas, el principal centro de distribución de este molusco sagrado estaba precisamente en La Plata, una pequeña isla ubicada frente al Ecuador (9), en el Golfo de Guayaquil. Pero quienes se dedicaban -y todavía lo hacen - a extraerlas debían tener pulmones de acero. A 15, 60, a veces más, metros de profundidad crece la joya de los mares turquesa. (Nota 28)

En dicha isla se han encontrado huellas de un intenso intercambio comercial en cerámica de diferentes procedencias como Lambayeque, Mochica, Chimú, inca, y también culturas ecuatorianas y centroamericanas (Nota 29). Quién sabe si las grandes balsas que vieron los primeros conquistadores que llegaron a Tumbes, no eran otra cosa que transportes que llevaban el preciado molusco hacia el sur o el norte, para ser ofrendados a una deidad secular o para adornar la tumba de un rey chimú. El control del tráfico de Spondylus, y en su defecto, de mullu, fue entonces vital para la economía de pueblos costeros y andinos.

\subsubsection{Madre de todas las aguas}

Las conchas y sus derivados, mullus y chaquiras, tenían una monta y crédito excepcionales. Se las llamaba "hijas del mar" y "madre de todas las aguas". Ofrenda preferida para dioses y muertos, en cuyas tumbas aparecen talladas y quebradas en forma de figurillas humanas o zoológicas.

Asimismo, la gran demanda de conchas rojas, chaquiras y mullus, alimentaban los ritos hogareños y los peregrinajes a santuarios como Pachacamac, Pariacaca, Apo Catequil, Huarivilca, Chavín de Huantar, etc. Las huacas no podían carecer de ellas.

También eran piezas talismánicas, protectoras contra todo tipo de males. Su posesión implicaba necesidad de importarlas para atraerse los favores divinos, abundantes 
lluvias, y satisfacer las necesidades de expresión simbólica en unas relaciones sociales donde era tan importante el intercambio y el trueque.

Ahora los viejos dioses del Spondylus han vuelto. Pero ya no traen la abundancia o la carencia, sino la paz. (10)

\subsubsection{Pago con sencillo}

El valor de estas curiosas monedas-mercancía

Tres eran los productos utilizados por los pueblos andinos como "monedamercancía": el ají, por su rareza e importancia para sazonar los alimentos; la coca, vital en la vida del poblador serrano; y el Spondylus o mullu, que se utilizaba también para fabricar las conocidas chaquiras. Los estudiosos coinciden en señalar que este último, sin vacilar, fue el más importante.

"El mullo o chaquira -escribe el historiador Waldemar Espinoza Soriano-, por proceder de las caracolas exóticas tan justipreciadas y vinculadas a la vida religiosa del mundo andino. Lo que no se conoce son los montos que se podía comprar de chaquira. Su valoración debieron hacerla de distintas maneras pero las desconocemos. De todos modos, chaquiras, ají y coca unas veces serían utilizados por unidades y otros en sartas dependiendo su valor de la longitud, comparándolas con las del ser humano, ya que todas las medidas andinas emanaban de éste, por considerársele la unidad de los cómputos..." *

Los investigadores no se han puesto de acuerdo a lo que se podía comprar con mullu convertido en chaquiras. En un documento de 1543, Vaca de Castro afirma que con ellas se retribuía el trabajo de quienes atendían los tambos y el de los cargadores de mercaderías de un tambo a otro (Nota 30). También se utilizaba para utilizar a los 
médicos, menestrales, curacas, guerreros, etc. Se les conceptualizaba como objetos destinados para la regulación del comercio y transporte de valores entre personas, una forma de pago generalmente aceptada.

* "ARTESANOS, TRANSACCIONES Y FORMAS DE PAGO EN EL MUNDO ANDINO. SIGLOS XV Y XVI" Banco Central de Reserva del Perú, Lima, 1987

\section{Parte II. Lugares de por acá (... y de más o menos allá)}

\subsection{Perú para todo el mundo}

(Artículo publicado en el Suplemento Dominical de OJO, el domingo 01 de agosto de 1993, pp. 10)

No hay uno sino muchos Perú. Claro que no estamos hablando de la tan celebrada variedad racial y multicultural de nuestro país sino de otros aspectos más curiosos y anecdóticos acerca de la presencia del Perú en todo el mundo, y en efecto, contra lo que se pudiera suponer, lo encontramos en los lugares más inverosímiles y exóticos.

Recorramos, pues, los cuatro puntos cardinales de esta Tierra para ir al encuentro del Perú.

Para empezar, el Diccionario de la Real Academia Española menciona que la palabra "Perú" es sinónimo de algo de mucha estimación y aprecio, de allí la famosa frase vale un Perú acuñada por los españoles en virtud de la gran riqueza en metales preciosos de su territorio. Por otro lado, el adverbio "Perú" significa por donde o donde quiera. (10)

También lo encontramos en otros idiomas. En la lengua vasca del norte de España, por ejemplo, Perú es el apodo cariñoso y popular de Pedro. 
Pero donde más aparece el nombre de nuestra patria es a lo largo y ancho del mundo, así tenemos:

Perú: Población de la República Argentina, en la provincia de Córdoba, departamento de Totoral.

Perú: Barrio rural de Cuba, en la provincia de Santa Clara, municipio de Corralillo.

Perú: Hacienda de México, en el estado de Coahuila, municipio de Torreón; Hacienda en el estado de Chiapas, municipio de Tapachula; Rancho en el estado de Durango, municipio de Ciudad León; Rancho en el estado y estrecho de Michoacán, municipio de Tepacaltepec. En dicho municipio hay otro rancho de igual nombre y otro en el estado de Hidalgo. 


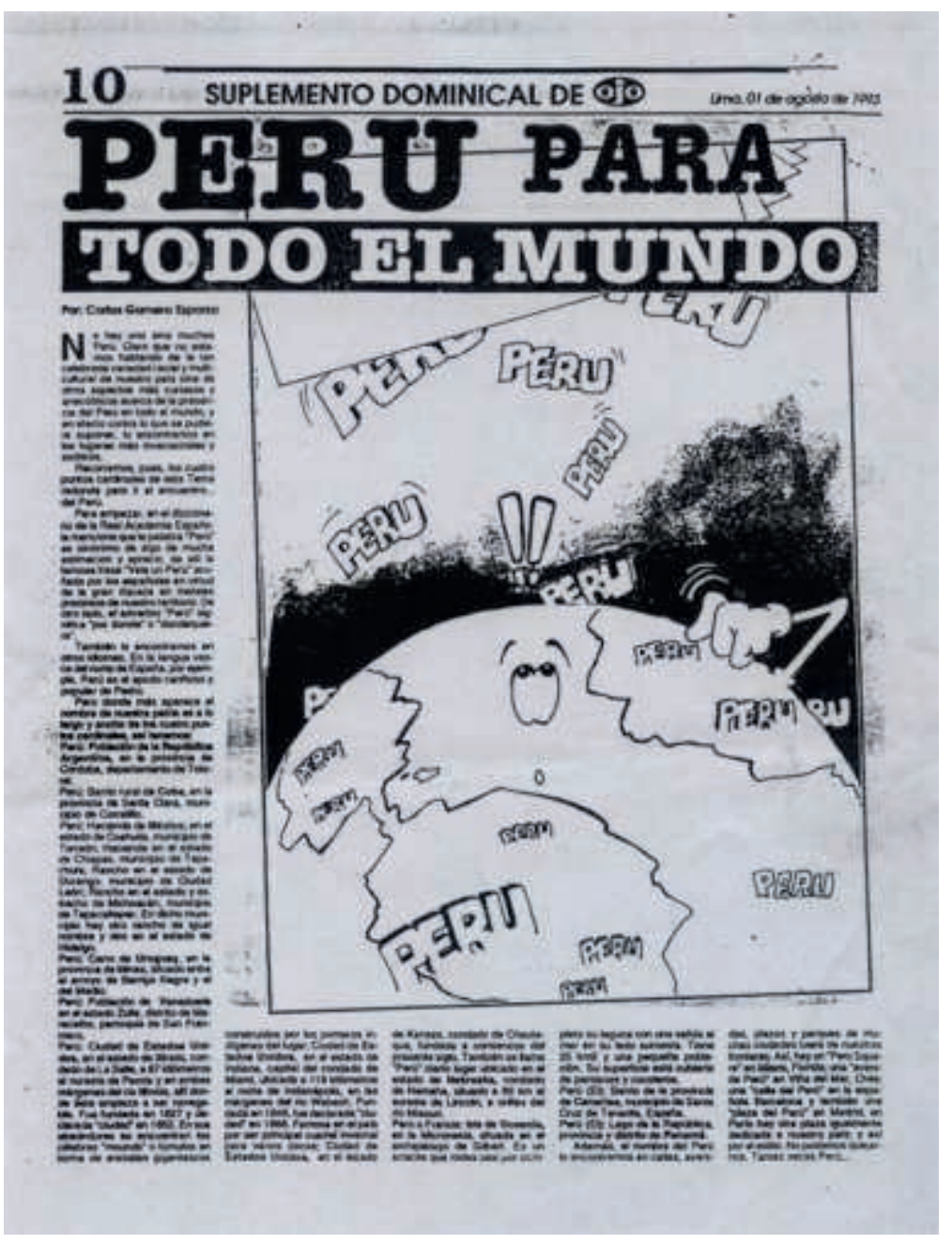

Figura 4. Recorte de "Perú para todo el mundo".

Perú: Cerro de Uruguay, en la provincia de Minas. Situado entre el arroyo de Barriga Negra y el del Medio.

Perú: Población de Venezuela, en el estado Zulia, distrito de Maracaibo, parroquia de San Francisco.

Perú: Ciudad de Estados Unidos, en el estado de Illinois, condado de La Salle, a 97 kilómetros al noreste de Peoria y en ambas márgenes del río Illinois, allí donde éste empieza a ser navegable. Fue fundada en 1827 y declarada "ciudad" en 1852. En sus alrededores se encuentran los célebres "mounds" o túmulos en forma de animales 
gigantescos construidos por los primeros indígenas del lugar; Ciudad de Estados Unidos, en el estado de Indiana, capital del condado de Miami, ubicada a 116 kilómetros al norte de Indianápolis, en las márgenes del río Wabash. Fundada en 1849, fue declarada "ciudad" en 1868, famosa en el país por ser cuartel invernal de varios circos; Ciudad de Estados Unidos, en el estado de Kansas, condado de Chautaqua, fundada a comienzos del presente siglo. (S. XX - N. de R) También se llama "Perú" cierto lugar ubicado en el estado de Nebraska, condado de Nemaha, situado a $89 \mathrm{~km}$. al sureste de Lincoln, a orillas del río Missouri.

Perú o Francis: Isla de Oceanía, en la Micronesia, situada en el archipiélago de Gilbert. Es un arrecife que rodea casi por completo su laguna con una salida al mar en su lado suroeste. Tiene $25 \mathrm{~km} 2$ y una pequeña población. Su superficie está cubierta de pantanos y cocoteros.

Perú (El): Barrio de la provincia de Canarias, Municipio de Santa Cruz de Tenerife, España.

Perú (El): Lago de la República, provincia y distrito de Panamá.

Además, el nombre del Perú lo encontramos en calles, avenidas, plazas y parques de muchas ciudades de otros países. Así, hay un "Peru Square" en Miami, Florida; una "avenida del Perú" en Viña del Mar, Chile; una "calle del Perú" en la española Barcelona y también una "plaza del Perú"; en París hay una plaza igualmente dedicada al Perú; y así por el estilo. No nos podemos quejar. Tantas veces Perú. (28)

\subsection{Yungay}

(Crónica publicada en el Suplemento Dominical de OJO, el domingo 24 de mayo de 1987, pp. 7) 
"El domingo 31 de mayo de 1970, a las 3:35 de la tarde, el mundo cambió..."

La camioneta ya dejaba Caraz, la ciudad de la dulzura, y ahora se deslizaba sobre una alfombra de flores que tapizaba el valle con alegres colores... Nos dirigíamos hacia el sur bajo la procesión nevada de la Cordillera Blanca que se perfilaba en medio de un añil profundo. La rara belleza del Callejón de Huaylas (Nota 31) nos llenaba los ojos de luz y color. Abajo, el rumor del río Santa se dejaba escuchar refrescando el paisaje.

El Huascarán (Nota 32), el gran camello blanco de los Andes peruanos, se apareció en la distancia con sus cumbres cubiertas por un penacho de nubes. Luego de cruzar el pequeño río Ancash (Nota 33), llegamos a un recodo del valle... "eso que ven es el cementerio de Yungay... la ciudad se extendía detrás..." nos explicaron.

Llegamos ante una grácil arcada, descendimos del vehículo y empezamos a caminar hacia el viejo cementerio que se erguía a lo lejos, coronado por la estatua del Cristo de brazos abiertos... "esto fue Yungay, la hermosa..."

\subsubsection{Mudo testimonio: 4 palmeras}

Frente a nosotros se extendía una gran planicie cubierta de hierba y retamas amarillas, podía ver los sinuosos senderos que parecían converger en el centro del valle, donde se levantaban como un mudo testimonio de lo que fue la plaza de Armas de la ciudad... cuatro palmeras... Arriba se elevaba imponente con sus dos picos blancos la mole del Huascarán, verdugo de Yungay.

Cuando empezamos a subir al cerro del cementerio, sentí los efectos de la altura... Arriba brillaba bajo el sol la gran imagen del Cristo, cuyos brazos abiertos, que antes bendecían la ciudad, ahora abrazan la campiña vacía. En Yungay todo es aplastante, 
todo te hace sentir el peso de la telúrica y trágica grandeza. El Huascarán empequeñecía todo lo que le rodeaba. Cuando llegamos arriba nos sentamos al pie del blanco Cristo de la soledad. Y junto a mis compañeros de viaje escuchamos el relato de la persona que nos guíala... "el domingo 31 de mayo de 1970, a las 3:35 de la tarde, el mundo cambió..." ¿Qué había pasado en aquella hora aciaga?... tras un siniestro silencio, la tierra se sacudió con mortal denuedo... "instantes después prosiguió el guía-, se escuchó un ruido que bajaba raudo por la garganta del Huascarán, se desprendió un gran trozo de hielo y roca del pico norte de la montaña y una gigantesca avalancha se lanzó sobre la ciudad... dos minutos después, Yungay, "la hermosa", había desaparecido del mapa, sepultada por un manto de lodo, hielo y rocas... treinta mil personas murieron en aquel "mare mágnum" que después de represar el río Santa, se lanzó sobre la ciudad de Caraz causando destrucción y muerte..." 


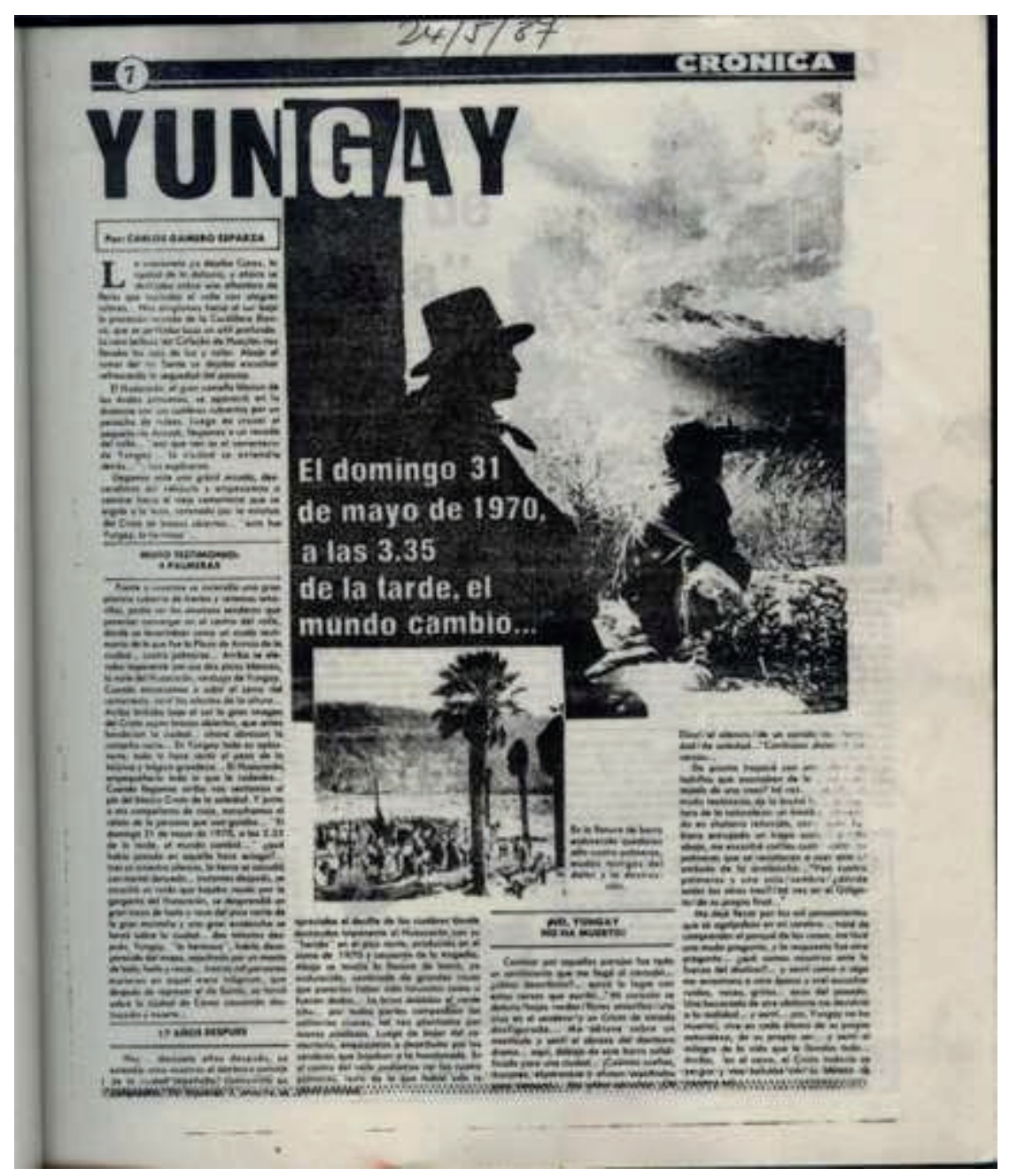

Figura 5. Recorte de "Yungay".

\subsubsection{7 años después}

Hoy... diecisiete años después, se extendía ante nosotros el dantesco paisaje de la ciudad sepultada, convertida en campo santo. De izquierda a derecha se apreciaba el desfile de las cumbres donde destacaba imponente el Huascarán con su "herida" en el pico norte producida en el sismo de 1970 y causante de la tragedia.

Abajo se tendía la llanura de barro, ya endurecida, sembrada de grandes rocas que parecían haber sido lanzadas como si fueran dados... La brisa doblaba el verde ichu 
(Nota 34)... por todas partes campeaban las solitarias cruces, tal vez plantadas por manos piadosas. Luego de bajar del cementerio, empezamos a deambular por los senderos que bajaban a la hondonada. En el centro del valle podíamos ver las cuatro palmeras, resto de lo que había sido la plaza principal.

\subsection{3. ¡No, Yungay no ha muerto!}

Caminar por aquellos parajes fue todo un sentimiento que me llego al corazón... ¿cómo describirlo?... quizá lo logre con estos versos que escribí... Mi corazón se detuvo / hojas verdes / flores amarillas / una cruz en el sendero / y un Cristo de mirada desfigurada... Me detuve sobre un montículo y sentí el abrazo del dantesco drama... aquí, debajo de este barro solidificado yace una ciudad... ¡Cuántos sueños, ilusiones; esperanzas y afanes sepultados para siempre!... "Mis oídos escuchan ¡oh, Dios! / el silencio / de un sonido / de eternidad / de soledad...", continúan diciendo los versos.

De pronto tropecé con una hilera de ladrillos que asomaba de la tierra ¿el tejado de una casa? tal vez... más allá, otro brutal testimonio de la furia destructora de la naturaleza: un ómnibus convertido en chatarra retorcida, como quien hubiera estrujado un trapo sucio... y más abajo me encontré con las cuatro solitarias palmeras que se resistieron a caer ante el embate de la avalancha... "Veo cuatro palmeras y una sola / sombra / ¿dónde están las otras tres? / tal vez en el Gólgota / de su propio final..."

Me dejé llevar por los mil pensamientos que se agolpaban en mi cerebro... traté de comprender el porqué de las cosas, me hice una muda pregunta y la respuesta fue otra pregunta... ¿qué somos nosotros ante la fuerza del destino?... y sentí como si algo me arrastrara a otra época y creí escuchar ruidos, voces, gritos... ecos del pasado. 
Una bocanada de aire sibilante me devolvió a la realidad... y sentí... ¡no, Yungay no ha muerto!, vive en cada átomo de su propia naturaleza, de su propio ser... y sentí el milagro de la vida que lo llenaba todo...

Arriba, en el cerro, el Cristo todavía se yergue y nos bendice con su abrazo de viento y sol.

En los últimos años se han descubierto bellos murales bajo capas de pintura.

\subsection{Trujillo, la ciudad pintada}

(Reportaje publicado en el Suplemento Dominical del diario OJO, el domingo 13 de mayo de 1990, pp. 12 - 13 - Con texto y fotos del autor)

"Ciudad pintada", dicen ahora los guías turísticos. Ciudad pintada pero nadie parece darse cuenta. Ciudad pintada y, sin embargo, parece mentira. Y no es Sevilla (11 12), ni qué Sevilla. Ahora más parece una ciudad morisca. La hermosa capital de la eterna primavera tiene un motivo más para sentirse orgullosa. Ya no es la marinera, guitarra y cajón; ni los caballos de paso peruanos; ni las calles olvidadas de ChanChan (Nota 35); ni mucho menos el fierro entretejido de sus venerables ventanas... o sus viejas historias de amoríos y pasiones, de encajes y filigranas. Ahora la señorial Trujillo tiene otro adjetivo: ciudad pintada, así es.

\subsubsection{Se descubrieron de casualidad}

En realidad, esta historia data de 1985, cuando el gobierno decidió que "ésta es la hora de Trujillo"... y entonces comenzó una serie de reconstrucciones de iglesias, conventos y casonas coloniales. 
A alguien se le ocurrió la genialidad de "raspar" la pintura de una antigua mansión ubicada cerca de la Plaza de Armas. La sorpresa fue mayúscula. Debajo de capas y capas de pintura apareció un enlucido de yeso, y debajo de éste, se descubrieron los murales más hermosos del Perú. Lo mismo ocurrió simultáneamente con otra casona, y luego otra y otra. Con esto se llegó a la conclusión de que antaño Trujillo fue una ciudad pintada.

\subsubsection{Pinturas por donde sea}

Y las sorpresas continuaron. Pronto se cayó en cuenta que no sólo las fachadas estaban pintadas. También lo estaban los zaguanes, los patios, los pasillos, las salas, los tejados y hasta los pisos... estos eran los dibujos más bellos que se habían visto. Figuras geométricas, artísticos diseños que parecen imitar a los azulejos sevillanos. (12) Los portales blasonados aparecieron coloreados con trazos floridos y madreselvas. Y cada casona tenía lo suyo, como por ejemplo en la Casa Lynch, ubicada en la primera cuadra de la calle Independencia; allí se encontró una hermosa fachada con graciosos rombos en blanco y rojo. Una obra de arte que estuvo escondida por siglos de capas de brocha gorda.

También se da el caso de que la remodelada Casa Orbegozo (13) presenta rezagos de bellos murales muy antiguos en su patio principal. Por otra parte, la vieja residencia hoy ocupada por la "Casa de la Cultura" es tal vez una de las mejores muestras de la pintura muralista colonial. Su fachada es un canto al buen gusto, allí se han descubierto falsos azulejos sevillanos pintados con tal maestría que parecen verdaderos. Los restauradores han tenido el buen tino de respetar el estilo original de la casa, incluyendo la portada, donde uno puede darse una idea de su pasado esplendor. Ahora es un centro cultural y sala de exposiciones. 


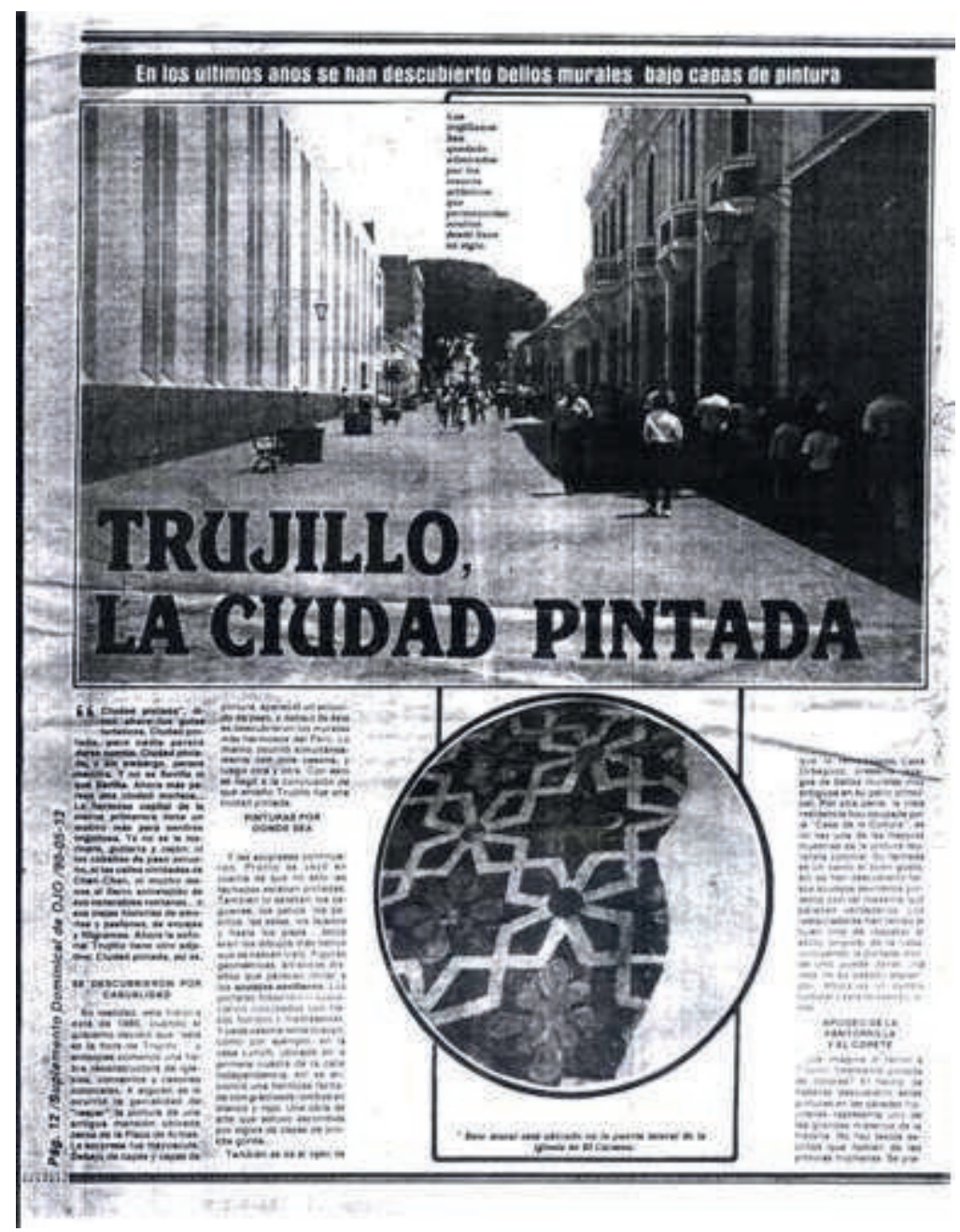




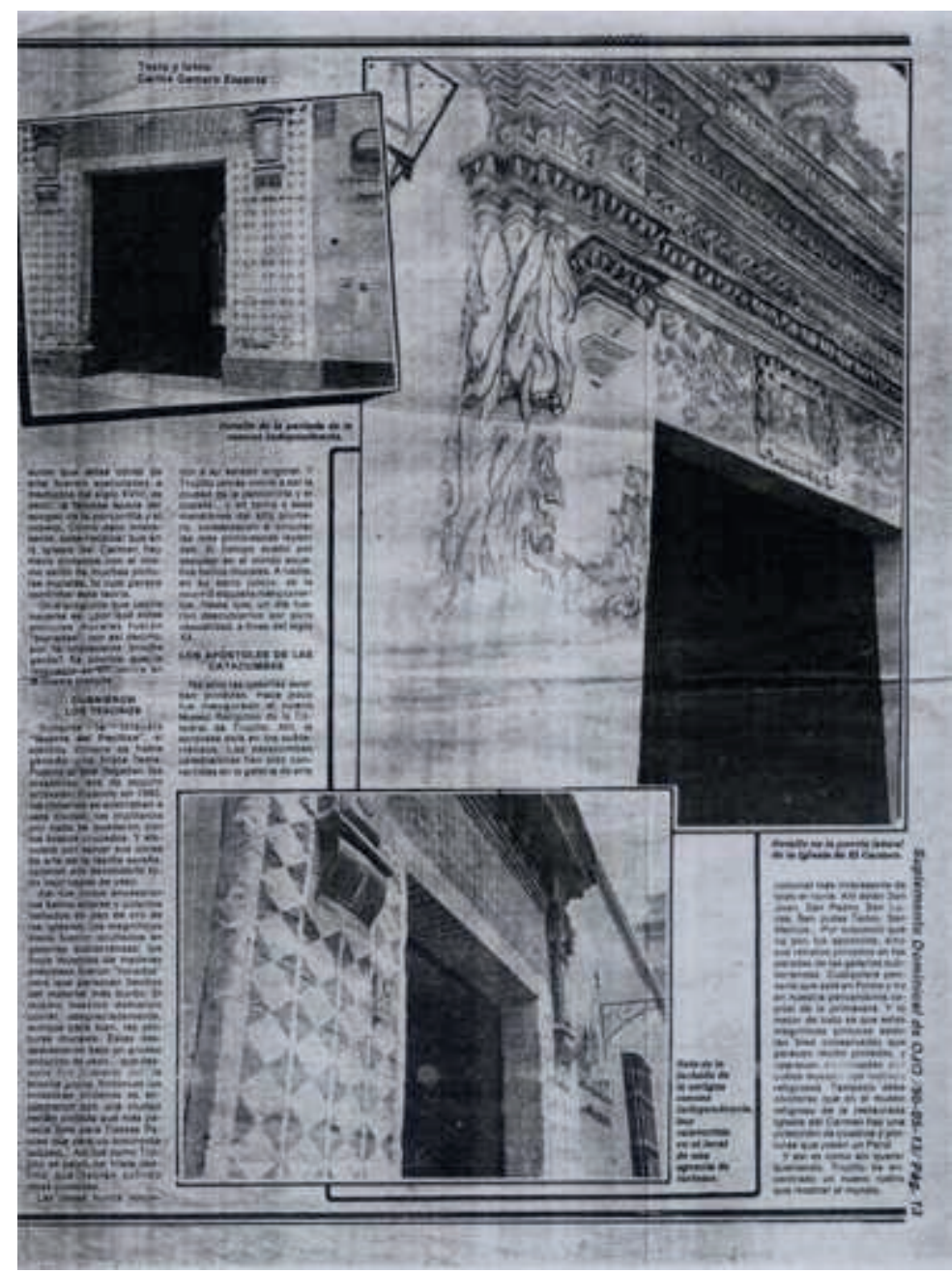

Figuras 6a. y 6b. Recortes de "Trujillo, la ciudad pintada".

\subsubsection{Apogeo de la pantorrilla y el copete}

¿Se imagina el lector a Trujillo totalmente pintada de colores? El hecho de haberse descubierto estas pinturas en las paredes trujillanas representa uno de los grandes misterios de la historia. No hay textos escritos que hablen de las pinturas murales trujillanas (Nota 36). Se presume que estas obras de arte fueron ejecutadas a mediados del siglo XVIII, es decir, la famosa época del apogeo de la pantorrilla y el copete (Nota 37). Como dato interesante, cabe recalcar que en la Iglesia del Carmen 
hay óleos pintados con el mismo estilo de muchas pinturas murales, lo cual parece confirmar esta teoría.

Otra pregunta que cabría hacerse es: ¿por qué estas pinturas murales fueron "borradas", por así decirlo, por la implacable brocha gorda? Es posible que la respuesta se encuentre en la misma historia.

\subsubsection{Cubrieron los tesoros...}

Durante la infausta guerra del Pacífico (14), el ejército chileno se había ganado una triste fama. Pueblo al que llegaban los invasores era de seguro arrasado. Cuando en 1882 los chilenos se acercaban a la ciudad, los trujillanos por nada se quedaron con los brazos cruzados. Y afanosos por salvar sus obras de arte de la rapiña sureña, optaron por esconderlo todo bajo capas de yeso.

Así fue como enyesaron los bellos altares y púlpitos bañados en pan de oro de las iglesias, los magníficos óleos fueron ocultados en galerías subterráneas. Los finos muebles de maderas preciosas fueron "tocados" para que parezcan hechos del material más burdo. El mismo destino debieron correr, desgraciadamente para bien, las pinturas murales. Éstas desaparecieron bajo gruesas capas de yeso... que después fueron cubiertas por la pintura de agua. Entonces los invasores chilenos se encontraron con una ciudad recién pintada que más parecía lista para fiestas patrias que para un inminente saqueo. Así fue como Trujillo se salvó del triste destino que habían sufrido otras ciudades de la costa peruana.

Las casas nunca volvieron a su estado original. Y Trujillo jamás volvió a ser la ciudad de la pantorrilla y el copete... y en torno a estas mansiones del alto plumero comenzaron a circular las más pintorescas leyendas. El tiempo acabó por sepultar en el olvido aquellos bellos murales. A nadie, en su sano juicio, se le ocurrió siquiera 
mencionarlos. Hasta que un día fueron descubiertos, por pura casualidad, a fines del siglo XX.

\subsubsection{Los apóstoles de las catacumbas}

No sólo las casonas estaban pintadas. Hace poco fue inaugurado el nuevo Museo Religioso de la Catedral de Trujillo. Allí, la sorpresa está en los subterráneos. Las catacumbas catedralicias (15) han sido convertidas en la galería de arte colonial más interesante de todo el norte. Allí están San Juan, San Pedro, San Lucas, San Judas Tadeo... Por supuesto que no son los apóstoles sino sus retratos pintados en las paredes de las galerías subterráneas. Cualquiera pensaría que está en Roma y no en nuestra peruanísima capital de la primavera (Nota 38) (30). Y lo mejor de todo es que estas magníficas pinturas están tan bien conservadas que parecen recién pintadas; éstas aparecen enmarcadas por bellos frescos con motivos religiosos. Tampoco debe olvidarse que en el museo religioso de la restaurada Iglesia del Carmen hay una colección de cuadros y pinturas que ¡valen un Perú!

$\mathrm{Y}$ así es como, sin querer queriendo, Trujillo ha encontrado un nuevo rostro que mostrar al mundo.

Son bellos, conmovedores, poéticos, y algunos hasta humorísticos, los epitafios son...

\subsection{El alma de los panteones}

(Artículo publicado en el Suplemento Dominical de OJO, el domingo 9 de julio de 1989, pp. 10) 
Expresiones de amor, tristeza, gratitud, esperanza, fe, consuelo, religiosidad o imprecación, donde se desahoga el desconsuelo humano por lo irreparable, letras que viven eternamente por los mortales... éstos son los epitafios.

El Presbítero Maestro (Nota 39), como cualquier otro cementerio, es un mundo aparte dentro de otro. Los sepulcros son grandes o pequeños, suntuosos y humildes, pero tienen algo en común y ésa es la realidad a la que nadie puede escapar. La vigencia de la muerte tan solo ha podido ser paliada por el sentimiento humano.

No es fácil encontrarlos entre tantas tumbas... es como buscar una aguja en un pajar. Los epitafios aparecen ahí, muchas veces en los sitios más inesperados, pero todos comunican el mensaje del alma dolida, el sentir de los vivos por sus muertos queridos...

\subsection{1. "Apenas abriste tu párpado tierno..."}

En un viejo pabellón dedicado a niños pequeños, todos fallecidos en el siglo pasado (s. XIX. N. de R.), se encuentran tal vez los más bellos, conmovedores y poéticos; son un delicado y dulce canto a la vida. Vino para dejarnos su memoria / un ángel fue que reclamó la gloria. (María Alejandrina Marrón, fallecida en 1866); Perdí a mi hijo / mas tengo el consuelo / de encontrarme con él / en el cielo (Antenor Ayllón, muerto a los 2 años y dos meses, sin fecha). Tal vez éste sea el más conmovedor: Apenas abriste tu párpado tierno / miraste el paterno regazo de Dios / y alzando del mundo tu vuelo / buscaste en... (frase inconclusa dedicada a la pequeña Luisa Amelia Delgado, fallecida a los cinco meses en 1865). 


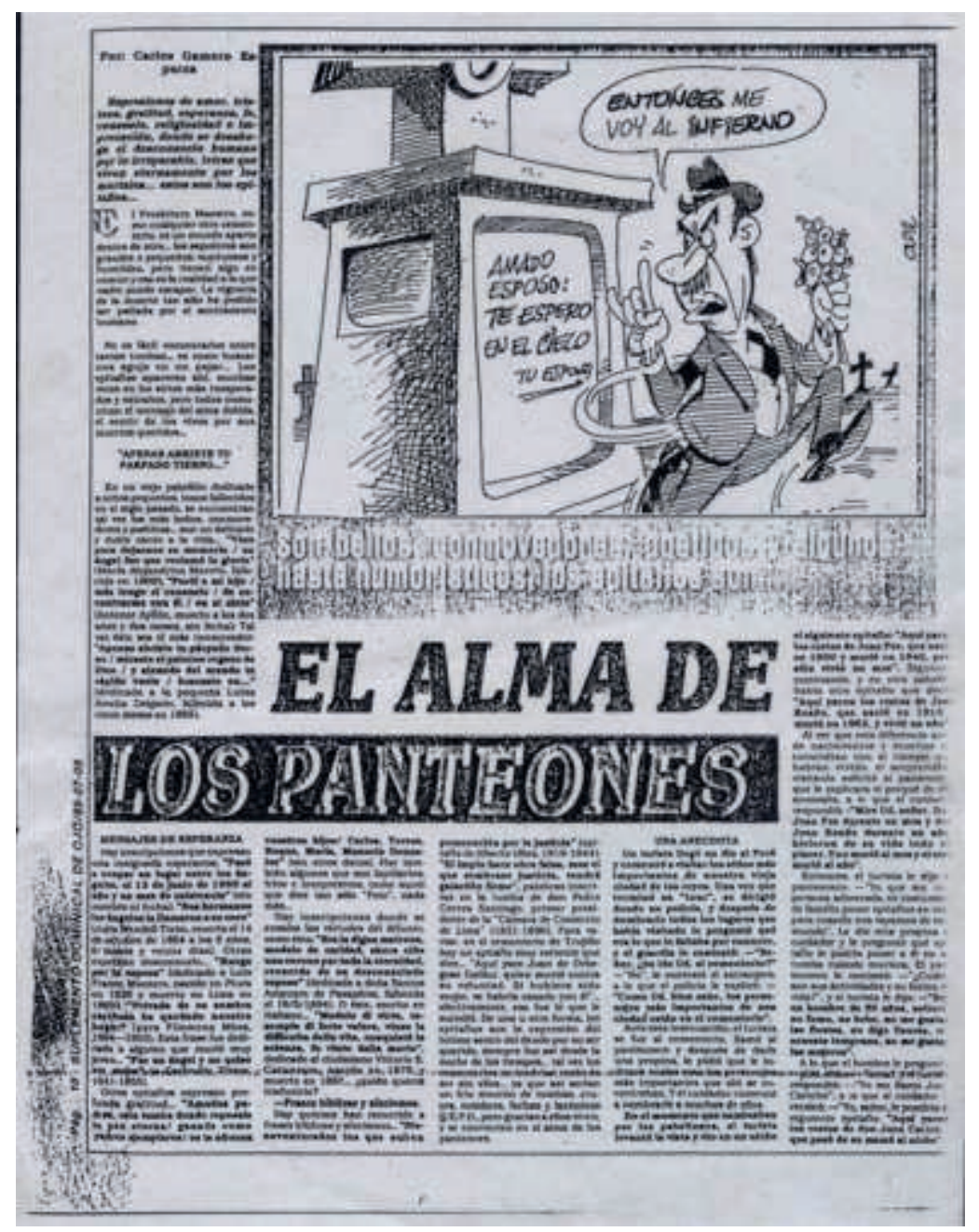

Figura 7. Recorte de "El alma de los panteones".

\subsubsection{Mensajes de esperanza}

Hay inscripciones que expresan una resignada esperanza: Pasó a ocupar un lugar entre los ángeles, el 12 de junio de 1866, al año y un mes de existencia (sin nombre ni fecha); Sus hermanos, los ángeles, la llevaron a su coro. (Julia Wendell Tizón, muerta el 14 de octubre de 1864 a los 8 años, 6 meses y veinte días) Otras expresan desconsuelo... Ruega por tu esposa (dedicado a Luis Franco Montero, nacido en Piura y muerto en Lima en 1869); Privada de su sombra cariñosa ha quedado nuestro hogar (para Filomena Meza, 1884 - 1903). Esta frase fue dedicada a alguien que 
murió muy joven: Fue un ángel y no quiso ser mujer (a Gertrudis Vivero, 1841 1855).

Otros epitafios expresan profunda gratitud... Amados padres, esta tumba donde reposáis la paz eterna / ganada como padres ejemplares / os la ofrecen vuestros hijos / Carlos, Teresa, Roque, María, Manuela Gonzáles (sin otros datos). Hay también algunos que son lapidarios, fríos e inexpresivos, como aquel que dice tan solo "feto", nada más.

Hay inscripciones donde se ensalza las virtudes del difunto, como ésta: Era la digna matrona modelo de caridad, ahora ciñe una corona por toda la eternidad (dedicado a doña Santos Ampuero de Pasapérez, fallecida el 16/5/1894). O este, escrito en italiano... Modelo de vfrtu, essemplo di forte volere, vinse la difficolta della vita, conquistó la scienza, fu vinto della morte (dedicado al ciudadano Vittorio E. Catanzaro, nacido en 1855 y muerto en 1897), ¿quién querrá traducirlo?

\subsubsection{Frases bíblicas y aforismos}

Hay quienes han recurrido a este tipo de frases... Bienaventurados los que sufren persecución por la justicia (epitafio de Alberto Ulloa, 1919 - 1944); El impío hace obra falsa, mas el que sembrase justicia, tendrá galardón firme, palabras inscritas en la tumba de don Pedro Correa Santiago, primer presidente de la "Cámara de Comercio de Lima" (1831 - 1890). Para variar, en el cementerio de Trujillo (Perú - N. de VA.) hay un epitafio muy reciente que dice: Aquí yace Juan de Orbegoso Galliur, quien murió contra su voluntad. Si hubiera sido mujer se habría casado con él... efectivamente, eso fue lo que le sucedió. De una u otra forma, los epitafios son la expresión del íntimo sentir del deudo por su ser querido; siempre fue así desde la noche de los tiempos... tal vez los cementerios no tendrían razón de ser sin ellos... ya 
que así serían un frío montón de tumbas, cruces, nombres, fechas, y lacónicos QEPD, pero gracias a ellos viven y se convierten en el alma de los panteones.

\subsubsection{Una anécdota}

Un turista llegó un día al Perú y comenzó a visitar los sitios más importantes de nuestra vieja ciudad de los reyes. Una vez que terminó su "tour", se dirigió donde un policía, y después de nombrarle todos los lugares que había visitado le preguntó qué era lo que le faltaba conocer, y el guardia le contestó: Señor, ¿ha ido Ud., al cementerio? -No, le contestó el extranjero - . A lo que el policía le explicó -como Ud. bien sabe, los personajes más importantes de una ciudad están en el cementerio.

Ante esta insinuación, el turista se fue al cementerio, llamó al panteonero y, después de darle una propina, le pidió que le indicara cuales eran los personajes más importantes que ahí se encontraban. Y el cuidador comenzó a nombrarle a muchos de ellos.

En el momento en que caminaban por los pabellones, el turista levantó la vista y vio en un nicho el siguiente epitafio: Aquí yacen los restos de Juan Pez, quien nació en 1900 y murió en 1940, pero sólo vivió un mes. Siguieron caminando, y en otro pabellón había otro epitafio que decía: Aquí yacen los restos de Juan Reaño, que nació en 1910 y murió en 1962, y vivió un año. Al ver que esta diferencia entre nacimientos y muertes no coincidía con el tiempo que habían vivido, el sorprendido visitante solicitó al panteonero que le explicara el porqué de esta anomalía, a lo que el cuidador le respondió: -Mire Ud. señor, don Juan Pez, durante un mes y don Juan Reaño durante un año hicieron de su vida todo un placer. Uno murió al mes y el otro murió al año. 
Entonces, el turista le dijo al panteonero: -Yo, que soy una persona adinerada, es costumbre de familia poner epitafios en vida para cuando nos vayamos de este mundo - . Le dio otra propina al cuidador y le preguntó qué epitafio le pondría a él en su tumba cuando muriera. El panteonero le contestó: -¿Cuáles son sus actividades y su forma de vida? - , y el turista le dijo: -Soy un hombre de 50 años, no fumo, no bebo, no me gustan las fiestas, no digo lisuras, me acuesto temprano, no me gustan las mujeres.

A lo que el hombre le respondió: -Ud. cómo se llama - , y el turista respondió: -Yo me llamo Juan Caricho - , a lo que el cuidador recalcó:

-Yo, señor, le pondría el siguiente epitafio: "Aquí yacen los restos de don Juan Caricho, que pasó de su mamá al nicho".

\subsection{Los pájaros vienen a morir al Perú}

(Reportaje publicado en el Suplemento Dominical de OJO, el domingo 22 de marzo de 1998, pp. $10-11)$

Muerte, desolación, hambre. El drama de muchas aves en el litoral limeño conmueve y preocupa. No olvidemos su importante rol ecológico y salvémoslas ahora.

El piquero de alas grises y pecho blanco se pasea tembloroso por la baranda del rompeolas del Regatas. Encima, las gaviotas inmóviles, que parecen flotar con sus alas extendidas, otean el bullicio de la Costa Verde como buscando algo que se les perdió. Los pelícanos se han adueñado de los rompientes de rocas erizadas donde las olas saltan en mil espumas; revienta la mar azul, verde, ocre, en todas las moléculas de la desesperanza. Los guanayes revolotean buscando algún pez esquivo entre los botes del muelle de Chorrillos, varados por una insomne calma chicha. 
El piquero mira con sus ojazos inquietos el ventanal del restaurante "Vivaldi" del Regatas, lleno de comensales. De repente algo le asusta y emprende el vuelo, pero al rato regresa. Su andar nervioso lo delata: tiene hambre. Frente a la playa, una mancha de pajarillos nada sobre el mar, meten el pico bajo el agua, muerden algo, nada, muerden agua salada y a cada picotazo más les atenaza el hambre. A su lado, los niños ríen, chillan, agitan las piernas, chapotean con sus salvavidas y tablas hawaianas de juguete, están felices disfrutando, ajenos al drama. Mar adentro, en unos elegantes yates, unas tangas toman sol, unos chicos bronceados brindan con espumante bebida.

Los niños corren en la terraza del Regatas, las jovencitas se despliegan espléndidas sobre la arena ardiente. En el alfombrado restaurante, el olor a vino, pescado y mariscos atrae a las aves marinas. Mientras los mozos, camisa tiza y negro pantalón, van de aquí para allá con sus bandejas. Para la gente todo está bien, todos conversan, alguno que otro despistado ha perdido sus cosas en el laberinto de espaldas y torsos, pero todo está bien bajo la canícula.

Pero no saben que los pájaros vienen a morir al Perú.

La larga avenida de la Costa Verde está colmada con todos los colores y ruidos del verano: combis enloquecidas que persiguen a sus ocasionales pasajeros, gente de todas las edades que bajan por los tortuosos senderos de los acantilados resecos... ¿Costa Verde? No sabemos a quién se le ocurrió ponerle ese nombre, tal vez alguna vez fue verde, tal vez los chorrillos de agua limpia caían desde arriba creando arroyos verdes que corrían junto a la pista; ducha fresca para los acalorados bañistas en lugar de aguas servidas. Ahora no, ni aguas servidas hay, nada; sólo polvo, gritos y sudores; bocinazos y gente tumbada en la playa inmensa; sombrillas mil como hongos amarillos, verdes, azules, rojos, anaranjados, blancos, se pierden a lo lejos; un enjambre humano en busca de sol y mar. En Barranquito, unos niños de piel tostada 
corretean tras una sucia pelota de hule sobre una ardiente losa de cemento. Más allá, un fornido salvavidas observa el horizonte de las olas.

Pero no saben que los pájaros vienen a morir al Perú.

En el horizonte perfilado por las islas de El Callao, que apenas se ven, vaporosas y azuladas, las bolicheras duermen su modorra... No hay pescao, dicen los viejos hombres de mar, curtidos en mil faenas. No hay pescao, pues, por eso las aves guaneras han abandonado sus islas, han dejado sus rocas, han dejado sus nidos y han volado hasta la costa de los hombres, a ver si éstos les dan de comer... han volado hasta la costa para quedar tirados en los arenales, en las calles indiferentes.

Es el despelote... del Niño, dicen; el chiquillo maloso ha enloquecido todo, clima y aguas. Y se ha llevado los peces mar adentro, muy adentro, hasta profundidades inaccesibles para los pájaros, para los hombres.

La algazara desordenada de la Costa Verde sigue su curso, las horas pasan, es domingo. Un domingo de sofoco. Es verano, pero no un verano cualquiera. La gente bulle por todas partes. Las carretillas de helados amarillos, verdes, blancos, rojos, azules, no apagan la sed. 


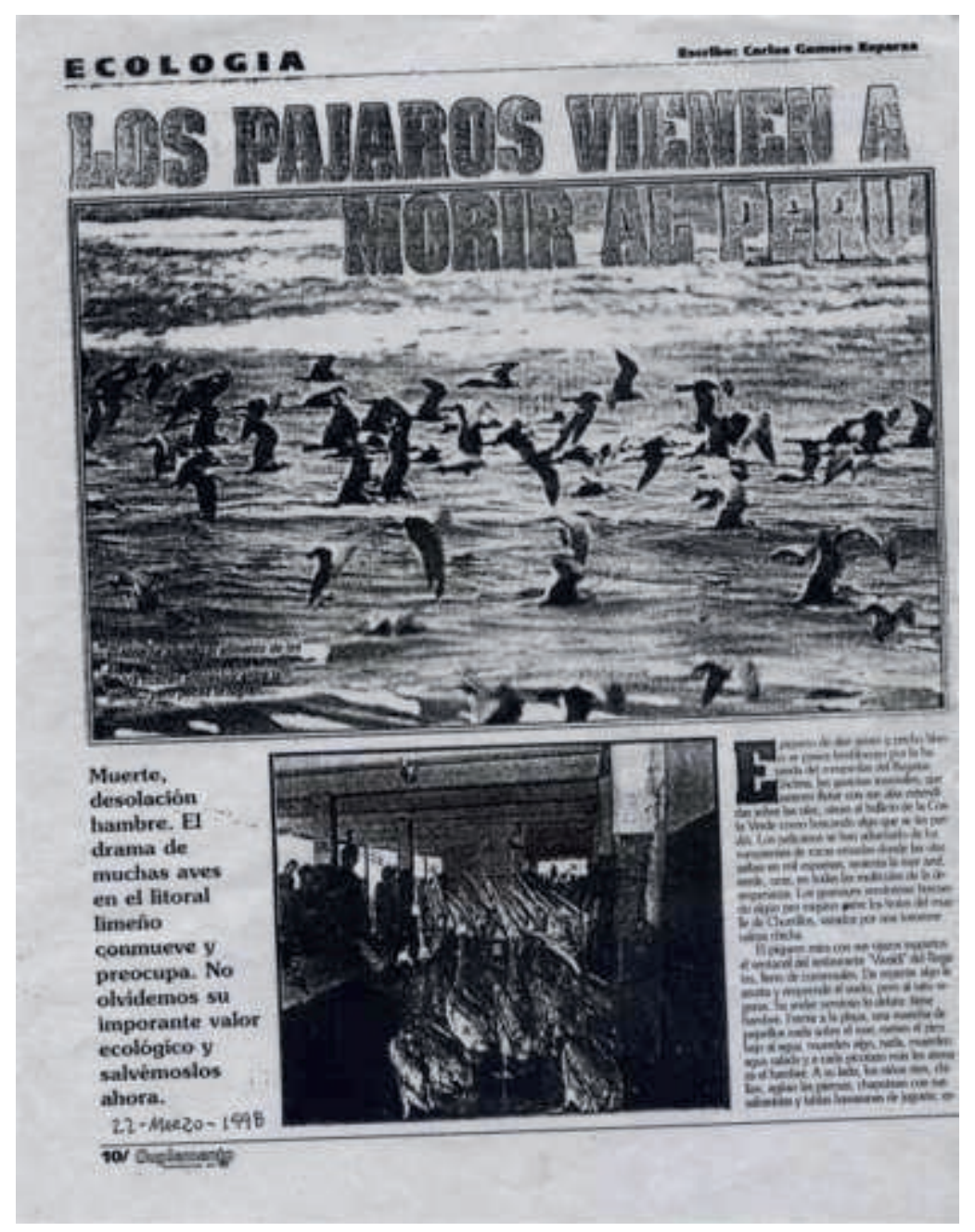




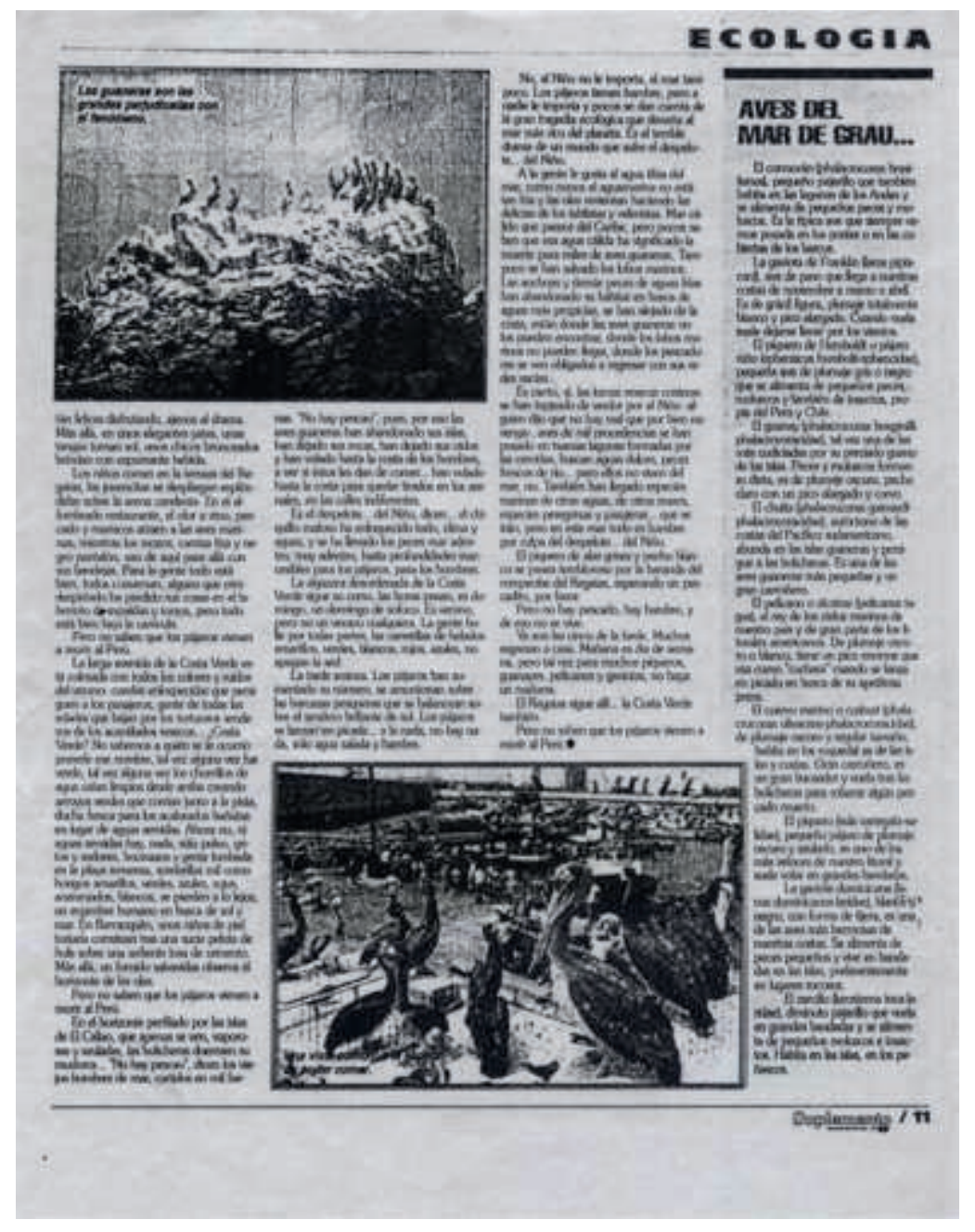

Figuras 8a. y 8b. Recortes de "Los pájaros vienen a morir al Perú".

La tarde avanza. Los pájaros han aumentado su número. Se amontonan sobre las barcazas pesqueras que se balancean sobre el sendero brillante de sol. Los pájaros se lanzan en picada... a la nada; no hay nada, sólo agua salada y hambre.

No, al Niño no le importa, al mar tampoco. Los pájaros tienen hambre, pero a nadie le importa y pocos se dan cuenta de la gran tragedia ecológica que devasta al mar más rico del planeta. Es el terrible drama de un mundo que sufre el despelote... del Niño. 
A la gente le gusta el agua tibia del mar; como nunca el aguamarina no está tan fría y las olas revientan haciendo las delicias de los tablistas y veleristas. Mar cálido que parece del Caribe, pero pocos saben que esta agua cálida ha significado la muerte para miles de aves guaneras. Tampoco se han salvado los lobos marinos. Las anchoas y demás peces de aguas frías han abandonado su hábitat en busca de aguas más profundas; se han alejado de la costa, están donde las aves guaneras no los pueden encontrar, donde los lobos marinos no pueden llegar, donde los pescadores se ven obligados a regresar con sus redes vacías.

Es cierto, sí, las lomas resecas costeras se han tapizado de verdor por el Niño alguien dijo que no hay mal que por bien no venga -; aves de mil procedencias se han posado en nuevas lagunas formadas por las crecidas; buscan aguas dulces, peces de río... pero ellos no viven del mar, no. También han llegado especies marinas de otras aguas, de otros mares; especies peregrinas y pasajeras... que se irán; pero en este mar todo es hambre por culpa del despelote... del Niño.

El piquero de alas grises y pecho blanco se pasea tembloroso por la baranda del rompeolas del Regatas, esperando un pescadito, por favor.

Pero no hay pescado, hay hambre, y de eso no se vive.

Ya son las cinco de la tarde. Muchos regresan a casa. Mañana es día de semana, pero tal vez para muchos piqueros, guanayes, pelícanos y gaviotas, no haya un mañana.

El Regatas sigue allí... la Costa Verde también.

Pero no saben que los pájaros vienen a morir al Perú. 


\subsubsection{Aves del Mar de Grau}

El cormorán (phalacrocorax brasilianus), pequeño pájaro que también habita en las lagunas de los Andes y se alimenta de diminutos peces y moluscos. Es la típica ave que siempre vemos posada en los postes o en las cubiertas de los barcos.

La gaviota de Franklin (larus pipixcan), ave de paso que llega a nuestra costa de noviembre a marzo o abril. Es de grácil figura, plumaje totalmente blanco y pico alargado. Cuando vuela suele dejarse llevar por los vientos.

El piquero de Humboldt o pájaro niño (spheniscus-humboldt-sphencidae), pequeña ave de plumaje gris o negro que se alimenta de pequeños peces, moluscos y también de insectos, propio del Perú y Chile.

El guanay (phalacrocorax bouginili-phalacrocoracidae), tal vez una de las más codiciadas por su preciado guano de las islas. Peces y moluscos forman su dieta. Es de plumaje oscuro, pecho claro con un pico alargado y corvo.

El chuita (phalacrocorax gainardi-phalacrocoracidae), autóctono de las costas del Pacífico sudamericano, abunda en las islas guaneras y persigue a las bolicheras. Es una de las aves guaneras más pequeñas y un gran carroñero.

El pelícano o alcatraz (pelicanus fagus), el rey de los cielos marinos de nuestro país y de gran parte de los litorales americanos. De plumaje oscuro o blanco tiene un pico enorme que usa como "cuchara" cuando se lanza en picada en busca de su apetitosa presa.

El cuervo marino o cushuri (phalacrocorax olivaceus-phalacrocoracidae), de plumaje oscuro y regular tamaño, habita en los roquedales de las islas y costas. Gran 
carroñero, es un excelente buceador, y vuela tras las bolicheras para robarse algún pescado muerto.

El piquero (sula variagala-sulidae), pequeño pájaro de plumaje oscuro y azulado, es uno de los más veloces de nuestro litoral y suele volar en grandes bandadas.

La gaviota dominicana (larus dominicanus-laridae), blanca y negra, con forma de tijera, es una de las aves más hermosas de nuestras costas. Se alimenta de peces pequeños y vive en bandadas en las islas, preferentemente en lugares rocosos.

El zarcillo (larustema inca-laridae), diminuto pajarillo que vuela en grandes bandadas y se alimenta de pequeños moluscos e insectos. Habita en las islas, en los peñascos.

Fuente: Museo de Historia Natural, Lima.

\subsection{Recuerdos del Vaticano}

(Crónica publicada en el Suplemento Dominical de OJO, el domingo 26 de marzo de 1988, pp. 5)

Nota: Remembranzas de un viaje realizado por el autor a Roma en noviembre de 1977

En la residencia papal se guardan las más valiosas obras de arte del mundo: Miguel Angel, Rafael, Bramonten y Bernini; amén de ser la capital espiritual del cristianismo.

Esto es toda una sorpresa... llegamos ante una puerta pequeña de pobre decoración. Abrirla es entrar a otro mundo y encontrarse con la historia. ¿La capilla Sixtina? -Sí, 
la capilla Sixtina - , me dicen. (16) Lo primero que llamó la atención son unas hileras de asientos reclinables... -Siéntense nomás y miren el techo-, nos dicen. Lo hago y ¡oh, belleza! La mismísima creación del señor Miguel Ángel Bounarroti. -¿Ésta es la pintura que le quitaba el sueño al papa Julio II? ¡Ya no ya!... (Nota 40)- Si no fuera por esta obra de arte, realmente esta capilla no llamaría la atención... las hay mejores, pero aquí se reúnen los cónclaves para elegir a los papas desde hace siglos: este pequeño recinto es el verdadero centro del mundo católico, escondido entre grandes muros, enclavado en la gran vieja muralla del Vaticano, detrás de lo que hoy es el maravilloso museo del palacio de los papas.

Estaba sentado allí, mirando el techo -si no me dio tortícolis fue porque Dios es grande - y recordaba los últimos cuarenta o cincuenta minutos que había pasado... esa cara grande y regordeta con cara de asceta, ¿es Moisés? No sé, pero me transportó por las largas galerías del pasado, que momentos antes habíamos recorrido... corriendo ¡caramba!, que ya cerraban el museo. Pasé por la sala fenicia, la asiría, la egipcia, con sus imitaciones de tumbas faraónicas, donde las momias duermen su "eterno descanso" bajo techos azules, llenos de estrellas. Luego, esta suerte de túnel del tiempo. Los cuadros con rostros papales que parecen hacerme un guiño de sarcasmo. ¿Cuántos papas son? ¿200? ¿300? No sé...

Después, ¡qué alivio! ¡Las más bellas estatuas griegas y romanas os presento, señores!... no, esto no era un libro de historia ¡era la historia! Los dioses y las diosas romanas, los bustos de marmóreos emperadores "in memoriam", parecen flanquear el panorama de bóvedas pintadas, todo esto en paradójica contraposición con un mundo que odiaba la idolatría. No, ahora son obras de arte y esto es un museo. 


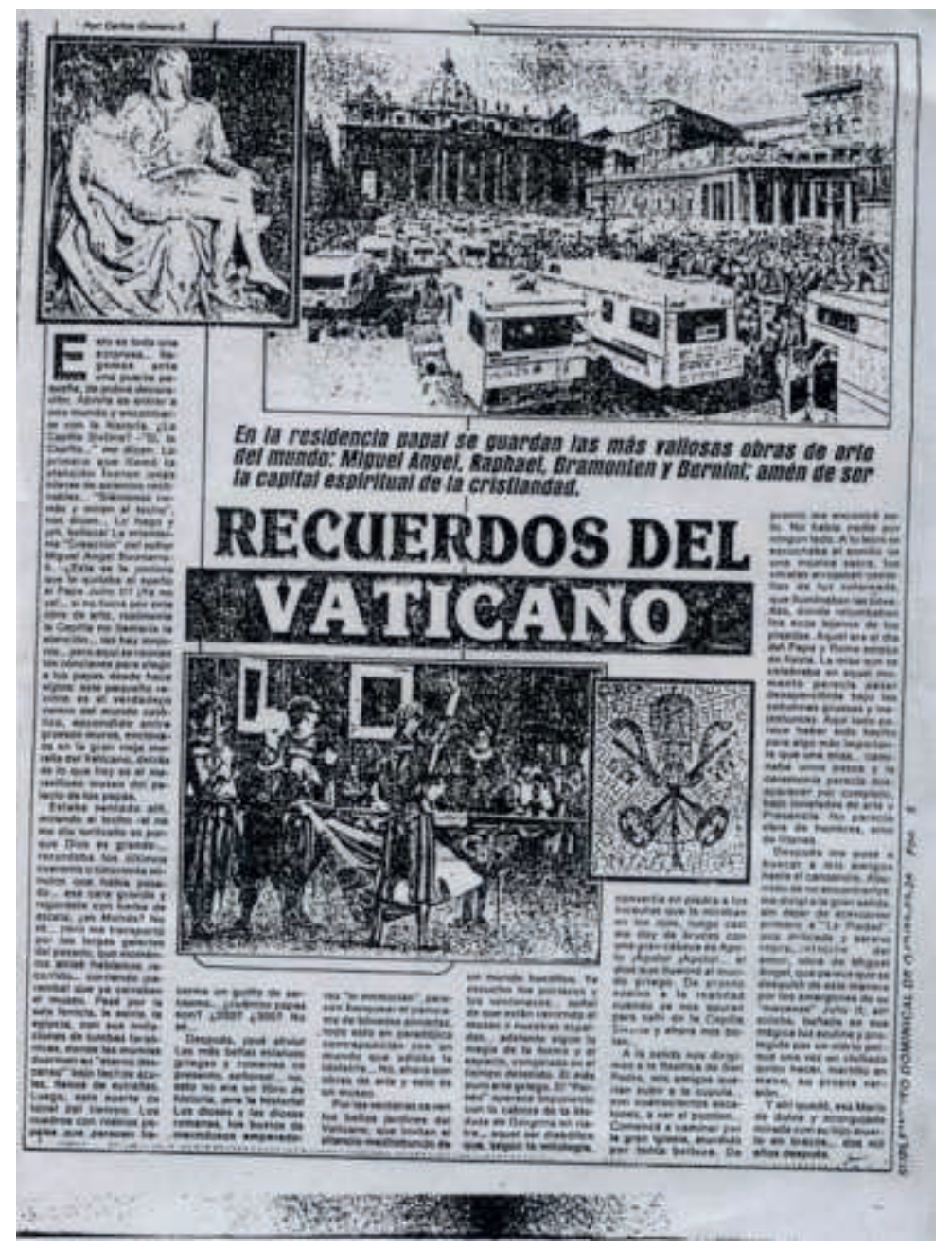

Figura 9. Recorte de "Recuerdos del Vaticano".

Por las ventanas se ven los bellos jardines del Vaticano, que invitan al silencio meditabundo en un mundo bucólico. Ya escucho los portazos y los ventanazos, señal de que están cerrando el museo a nuestras espaldas... adelante sigue la magia de la forma y el espacio, congelada en el tiempo detenido. El más puro arte griego, el "Perseo" aparece imponente con la cabeza de la Medusa de Gorgona en ristre... aquel ser diabólico que, según la mitología, convertía en piedra a los incautos que la miraban en los ojos; luego casi me doy de bruces con una gran cabeza de Apolo. ¡Apolo! ¡Apolo!... el dios que iluminó el mundo griego. De pronto vuelvo a la realidad cuando ya nos apuran para salir de la Capilla Sixtina, y ahora nos "botan"... 
A la salida nos dirigimos a la Basílica de San Pedro, mis amigos querían subir a la cúpula... son cuatrocientos escalones, a ver si pueden... Comencé a caminar por la gran iglesia, aturdido por tanta belleza. De pronto me encontré solo. No había nadie por ningún lado. A lo lejos se escuchaba el sonido de una música sacra, los vitrales arrojaban centellas de luz coloreada que iluminaban las bóvedas, donde retumbaban los ecos lejanos de las pisadas. Aquel era el día del Papa y Roma estaba de fiesta. La misa que se celebraba en aquel momento parecía pasar desapercibida bajo las columnas gruesas y majestuosas. Aquí todo parece haber sido hecho para algo más importante que una misa... caminaba unos pasos y la ceremonia parecía desaparecer por completo bajo toneladas de arte y Presencia. No parecía obra de hombres sino de titanes.

Después me puse a buscar a mis amigos hasta el cansancio. Aburrido de no encontrarlos, me dirigí a la gran salida, sin dejar de acercarme primero a "La Piedad", una delicada y serena representación del amor, obra de Miguel Ángel, que parece que se desquitó de esta manera por los amargones de su "mecenas", Julio II; allí estaba, bañada en esa mágica luz azulina, y protegida por un vidrio porque una vez un chiflado quiso hacer, martillo en mano, su propia versión...

Y ahí quedó, esa María de dulce y acongojada mirada con su hijo muerto en brazos... dos mil años después.

\subsection{Carsi: Encuentro con la casa familiar}

(Crónica publicada en el diario Correo de Lima, el 14 de marzo de 1974, pp. 11)

Nota: Este artículo ha sido transcrito tal como está en el original, con puntos y comas -vale decir, no se ha corregido ni "actualizado" nada-, por tratarse del primer trabajo periodístico realizado por el autor que, a la sazón, era colaborador casual del 
diario Correo de Lima. Como verá el amable lector, son obvias algunas faltas de sintaxis, las redundancias, ciertas informaciones inexactas y comprensibles la ortografía, por cuanto eran mis primeros pininos periodísticos. Es, en todo caso, un fresco y sabroso recuerdo de un viaje familiar realizado por Francia e Italia en agosto de 1974, época en la que quien escribe residía en Barcelona. ¡Bajo aquella canícula estaba muy, pero muy lejos de imaginar que este servidor vuestro llegaría a ejercer el periodismo... algún día!

Carlos Gamero Esparza es un joven peruano que se haya siguiendo estudios universitarios en Europa. Esta nota es el testimonio del reencuentro con la tierra de sus mayores: Carsi; tierra a la que también estuvo ligado por el afecto y por la sangre Luis Banchero Rossi.

La Costa Azul es quizás uno de los más bellos parajes del Mediterráneo; allá el mar es azul- verde, turquesa. La costa es accidentadísima y las playas se suceden de bahía en bahía.

Se podría decir que la Costa Azul es una inmensa urbe: Sólo tiene 30 a 60 kilómetros de longitud, los pueblos no distan unos de otros más de medio kilómetro, todos casi iguales, todos muy bien organizados y construidos. Hay muchos hoteles y hosterías y un turismo agobiante. Los pueblitos franceses son de ensueño, y Saint Tropez es el más famoso, qué duda cabe.

Allí fuimos a conocer el puerto; vimos infinidad de yates ipero qué yates! Los hay desde el diminuto de motor fuera de borda hasta el soberbio superyate o, un palacio flotante, mástiles y todo lo imaginable en materia náutica; los hay de todas partes, de Italia, España, Grecia, Israel y por supuesto también los franceses. 
Luego de Marsella a Cannes y Niza y de allí a Mónaco donde pude admirar el famoso Casino. La sala del edificio más famoso del Principado de Mónaco es bellísima, con murales en los cuatro costados y en el techo, las esquinas están llenas de esculturas, el piso y los contornos son de mármol; el edificio está rematado por fuera en una cúpula e imágenes en las cornisas. Es hermoso pero no muy imponente.

Saliendo de Mónaco para Italia uno se encuentra con una de las más atrevidas obras de ingeniería: la Autostrada Italiana. Se inicia en la frontera pasando por un impresionante puente que está en lo más alto de un valle que baja hacia el mar; después de pagar peaje se entra en un túnel larguísimo como de dos kilómetros, muy bien construido e iluminado con luces de sodio amarillas, estas luces aumentan gradualmente su intensidad conforme se acerca la boca del túnel y así la luz exterior no deslumbra.

Se ingresa luego a lo que llamaríamos una alfombra mágica porque se desliza prácticamente como suspendida de los abismos por sobre valles y ciudades enteras, cruzando las cordilleras por túneles. La carretera parece volar por los aires; si hay un valle profundo, con un río y una ciudad... ipues, la Autostrada pasa! ¿Y... si hay una cumbre? ¡Pues la Autostrada se introduce entre las rocas por túneles que tragan lo que encuentran a su paso! Hay partes en que la Autostrada se eleva y cruza valles enteros por encima de las cordilleras: abajo; los valles, ríos y pueblos; arriba: las nubes. ¡Así se llega a Génova!

Génova es una gran ciudad y tiene un puerto gigantesco, el más grande junto con el de Barcelona en todo el Mediterráneo. A primera vista es de un aspecto triste y sucio con sus oscuros edificios populares y las fábricas junto con las instalaciones portuarias; Génova es hermosa, pero más allá del puerto. 


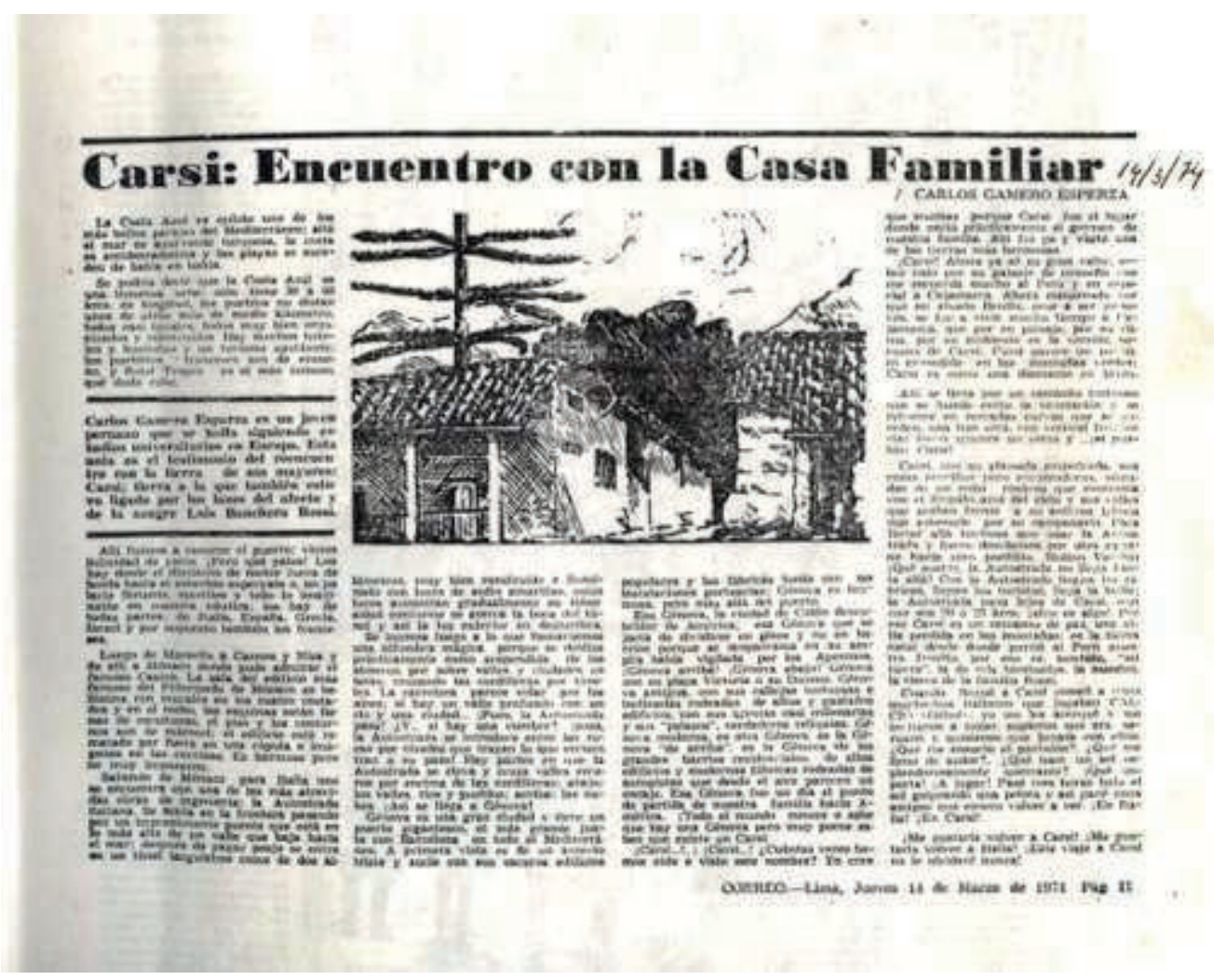

Figura 10. Recorte de "Carsi: encuentro con la casa familiar".

Esa Génova, la ciudad de Colón descubridor de América; esa Génova que se jacta de dividirse en pisos y no en barrios porque se desparrama en su amplia bahía vigilada por los Apeninos; ¡Génova arriba! ¡Génova abajo! Génova con su Plaza Victoria o su Duomo. Génova antigua, con sus callejas tortuosas e inclinadas rodeadas de altos y gastados edificios, con sus iglesias casi milenarias y sus "Palazos", verdaderas reliquias. Génova "de arriba", es la Génova de los grandes barrios residenciales, de altos edificios y modernas fábricas rodeadas de autopistas que desde el aire parecen un encaje. Esa Génova fue un día el punto de nuestra familia hacia América. ¡Todo el mundo conoce o sabe que hay una Génova pero muy pocos saben que existe un Carsi! 
¡Carsi...! ¡Carsi...! ¿Cuántas veces he oído o visto este nombre? Yo creo que muchas porque Carsi fue el lugar donde nació prácticamente el germen de nuestra familia. Ahí fui yo y visité una de las tierras más hermosas.

¡Carsi! Ahora ya sé su gran valor, sobre todo por su paisaje de ensueño que recuerda mucho al Perú y en especial a Cajamarca. Ahora comprendo por qué mi abuelo Benito, pese a ser genovés, se fue a vivir mucho tiempo a Cajamarca, que por su paisaje, por su clima, por su ambiente es la versión peruana de Carsi. Carsi parece un pueblito escondido en las montañas verdes; Carsi es como un diamante en bruto.

Allí se llega por un caminito tortuoso que se hunde entre la vegetación y se retuerce en cerradas curvas que se suceden, una tras otra, con vertical frecuencia; luego aparece un cerro y... jel pueblo: Carsi!

Carsi, con su plazuela empedrada, sus casas sencillas pero encantadoras, pintadas de un color rosáceo que contrasta con el límpido azul del cielo y sus calles que acaban frente a su antigua iglesia que sobresale por su campanario. Para llegar allá tuvimos que usar la Autostrada y luego desviarnos por otro camino hacia otro pueblito, Molino Vecchio. ¡Qué suerte, la Autostrada no llega hasta allá! Con la Autostrada llegan las fábricas, llegan los turistas, llega la bulla; la Autostrada pasa lejos de Carsi, aunque sea a 20 o $25 \mathrm{kms}$. ¡Algo es algo! Por eso Carsi es un remanso de paz, una villa perdida en las montañas; es la tierra natal desde donde partió al Perú nuestra familia, por eso es, también "mi tierra", la de mis bisabuelos, la nuestra, la tierra de la familia Rossi.

Cuando llegué a Carsi conocí a unos muchachos italianos que jugaban CALCIO (fútbol), yo me les acerqué y me invitaron a jugar. Supieron que yo era peruano y quisieron que jugara con ellos. ¿Qué me ensucio el pantalón? ¿Qué me lleno de sudor? ¿Qué hace un sol esplendorosamente quemante? ¡Qué importa! ¡A jugar! Pasé 
tres horas bajo el sol golpeando una pelota y así gané unos amigos que espero volver a ver. ¡En Italia! ¡En Carsi!

¡Me gustaría volver a Carsi! ¡Me gustaría volver a Italia! ¡Este viaje a Carsi no lo olvidaré nunca!

\section{Parte III. Ingas y mandingas}

\subsection{Abimael, el griego}

(Reportaje y entrevista publicada en Suceso, revista dominical del diario Correo, el domingo 24 de febrero de 1991, pp. 8)

Abimael Guzmán ya no es aquel fantasma semisagrado al que recurrían sus fanáticos fieles. Es un ser de carne y hueso, débil como cualquiera de nosotros, capaz de bailar danzas exóticas (Nota 41), chasquear los dedos y hasta beber más de la cuenta.

El doctor Artidoro Cáceres nos acerca en esta entrevista a la personalidad del líder subversivo y a sus particulares gustos...

Hay que reconocer que Sendero Luminoso es una secta, por lo tanto, tiene todas las características organizativas como funcionales de este tipo de instituciones... ¿Cuál es el verdadero significado de todo esto? ¿Por qué Abimael Guzmán se presenta ente el Perú y el mundo con este video tan lleno de extraños símbolos? (Nota 41) ¿Acaso ese Sendero Luminoso no es lo que la mayoría piensa? Estas y otras son las interrogantes que se hace el neuro-psicólogo Artidoro Cáceres cuando le pedimos nos comente el polémico video presentado días atrás por el presidente de la República.

(Entrevista grabada con grabadora portátil) 
Doctor Cáceres, suponiendo que esto es una secta, ¿cuál es su relación con la afición de Guzmán por el trago... ¿dipsomanía? ¿ritualismo?

"Hay algunas sectas que se reúnen para realizar ceremonias con características místicas, sagradas. Hay otras sectas que, inclusive, sacrifican animales... seres humanos, inclusive. Hay algunas sectas religiosas en las cuales se promueve el consumo de algunas sustancias, por ejemplo, por vía respiratoria como el incienso; o sustancias por vía digestiva como el hashis. Aquí en esta secta hemos asistido a una reunión social, no ritual. No es ritual en gran parte de lo que se ha exhibido..."

"Yo sé que hay una parte del video que no se ha exhibido al público en la que hay una mesa con banderas, con lo que parecían ser cirios... ésa es posiblemente una ceremonia ritual de tipo político, de secta ideológica. Pero en lo que hemos visto hay más bien una festividad; este festejo ha sido con licor, donde, inclusive, en determinados momentos se ve una botella de Jerez... y es posible que ellos hayan llegado a ese grado alcohólico, en especial el señor Guzmán, Abimael Guzmán, para decirlo más claramente, consumió seguramente alcohol en gran cantidad porque, como se puede ver, tenía todos los signos exteriores del ebrio." 


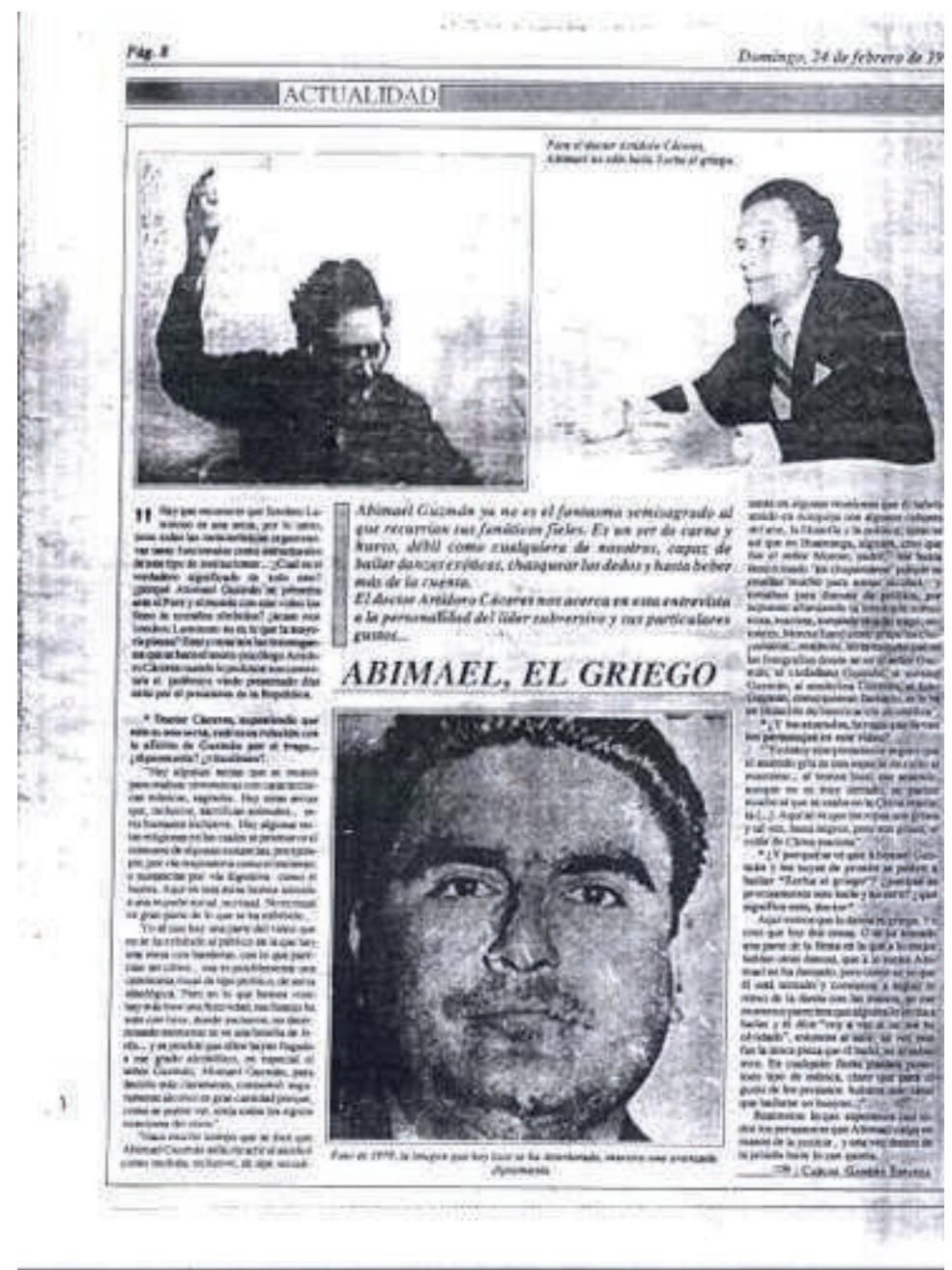

Figura 11. Recorte de "Abimael, el griego".

"Hace mucho tiempo se dice que Abimael Guzmán solía recurrir al alcohol como medida, inclusive, de tipo socializante en algunas reuniones que él habría tenido en Arequipa (Nota 42) con algunos cultores del arte, la filosofía y la política; tanto es así que en Huamanga (Nota 43), alguien, creo que fue el señor Morote, padre (Nota 44), los había denominado "los chupamaros" (Nota 45) porque se reunían mucho para tomar alcohol. Y tomaban para discutir de política, por supuesto afianzando la ideología comunista, maoísta, tomando mucho trago, entonces, Morote llamó a este grupo "los chupamaros" (Nota 45); entonces, no es extraño que en las fotografías donde se ve al señor Guzmán, al ciudadano Guzmán, al asesino Guzmán, al 
senderista Guzmán, al líder Guzmán, como quieran llamarlo, se le ve en situación de intoxicación alcohólica."

¿Y los atuendos, la ropa que llevan los personajes en este video?

"Yo estoy completamente seguro que el atuendo gris es una especie de culto al maoísmo... si vemos bien, ese atuendo, aunque no es muy cerrado, se parece mucho al que se usaba en la China maoísta (...) Aquí se ve que las ropas son grises, y tal vez, hasta negros, pero son grises, el color de China maoísta."

¿Y por qué se ve que Abimael Guzmán y los suyos de pronto se ponen a bailar "Zorba el griego"? ¿Por qué es precisamente este baile y no otro? ¿Qué significa esto, doctor?

"Aquí vemos que la danza es griega. Yo creo que hay dos cosas. O se ha tomado una parte de la fiesta en la que a lo mejor había otras danzas, que a lo mejor Abimael no ha danzado; pero como se ve que él está sentado y comienza a seguir el ritmo de la danza con las manos, en ese momento pareciera que alguien lo invita a bailar y él dice "voy a ver si no me he olvidado", entonces al salir, tal vez ésta fue la única pieza que él bailó, no lo sabemos. En cualquier fiesta pueden poner todo tipo de música, claro que para el gusto de los peruanos hubiera sido ideal que bailaran un huayno..." (Nota 46)

Realmente lo que esperamos casi todos los peruanos es que Abimael Guzmán caiga en manos de la justicia (Nota 47), y una vez dentro de la prisión baile lo que quiera. 


\section{2. ¡Qué buena promo...!}

De seguro, la promoción San Luis Gonzaga (36), que egresó del Colegio La Inmaculada en 1963, jamás se imaginaron la cantidad de hombres públicos que iba a dar dicha aula 25 años después. Aquella promoción fue realmente notable, no sólo por la disparidad y variedad de los individuos que la integraron, sino también por el hecho poco frecuente de haber dotado a nuestro país de distinguidas personalidades. Políticos, artistas, escritores, abogados, médicos, periodistas, economistas, empresarios, da cualquier promoción, pueden decir algunos, pero, sin embargo, cualquier promoción no da líderes en cada una de sus actividades.

(Reportaje publicado en Suceso, revista dominical del diario Correo, el domingo 14 de abril de 1991, pp. 8 -9)

Tal es la excepcionalidad de este grupo que inclusive tiene a sus ex integrantes a líderes que se pasaron a las filas de la subversión, como Julio César Mezzich, número dos de la organización terrorista Sendero Luminoso. Sin embargo, este personaje es realmente un lunar, si no veamos quienes la integraban: Carlos Blancas, ex ministro de Justicia; los ex diputados Manuel Piqueras (IU) y Luis Heysen (PAP); José María Salcedo, actual presidente de RTP; Iván Rivera, ex ministro de Industria durante el segundo gobierno de Belaunde; Ernesto Palacios, famoso tenor que ahora canta en la Scala de Milán; Luis Peyrano, conocido director teatral; Guiseppe Bertorini, quien fuera dirigente del Partido Comunista Italiano; el conocido abogado Guillermo Alejandro Arosemena; el actual embajador del Perú en Bolivia, Oscar Maúrtua; Bruno Podestá, investigador y empresario; Manuel Romero Caro, ex ministro de Industria y Turismo y actual director del diario Gestión; el abogado Javier Belaunde López de Romaña y, para remate, Julio César Mezzich, quien durante un tiempo fue sindicado como el número dos de Sendero Luminoso. 
Y, ojo, no sólo ellos llegaron a formar parte de un grupo social distinguido, también sus profesores. El rector de esa época era el Monseñor Fernando Vargas, actual Arzobispo de Arequipa, el Prefecto era Luis Bambarén y el padre espiritual, nada menos que el Monseñor Augusto Vargas Alzamora, actual Arzobispo de Lima. Tres jesuitas, tres personajes de personalidad muy fuerte y tres personas de opiniones y formas de pensar muy distintas.

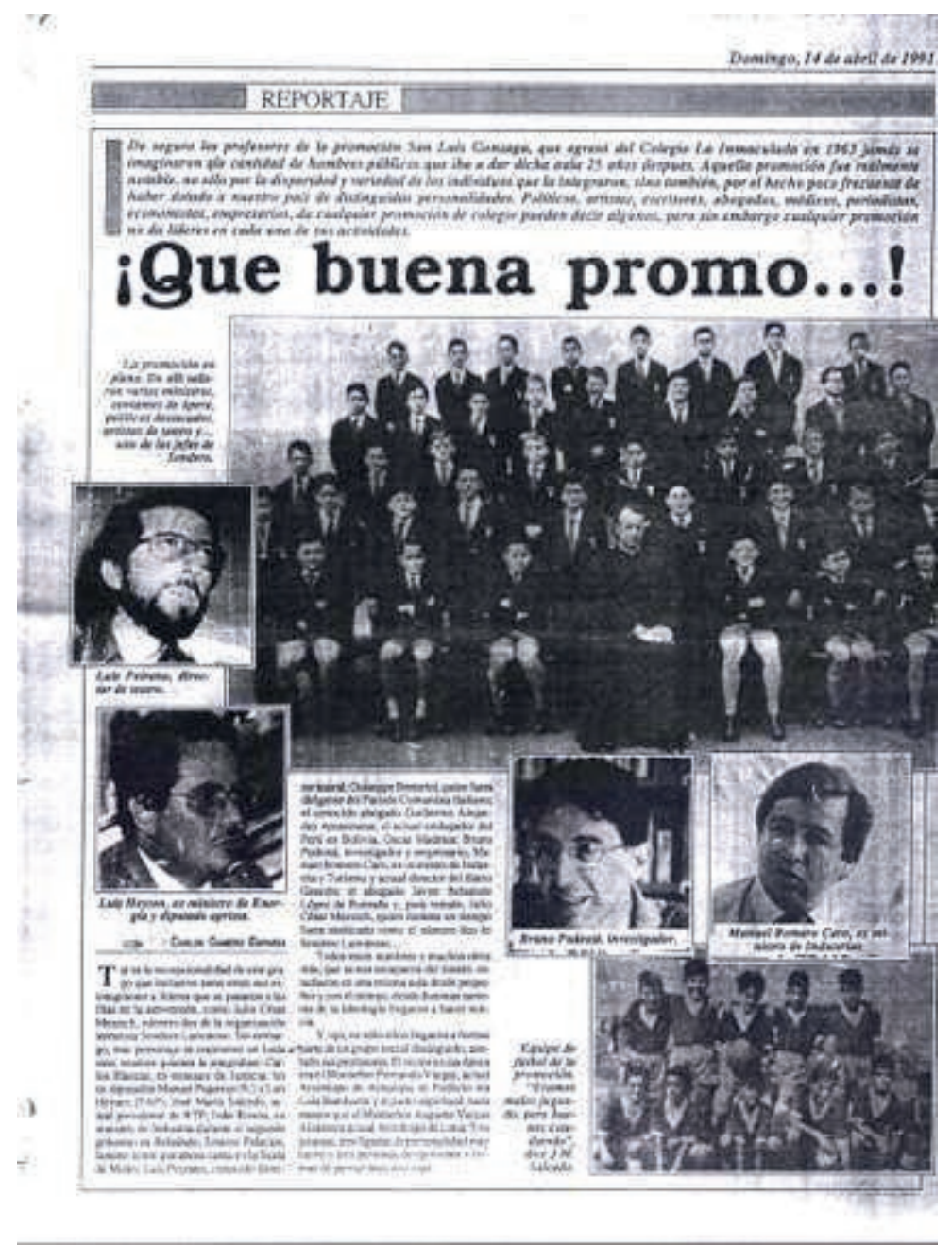




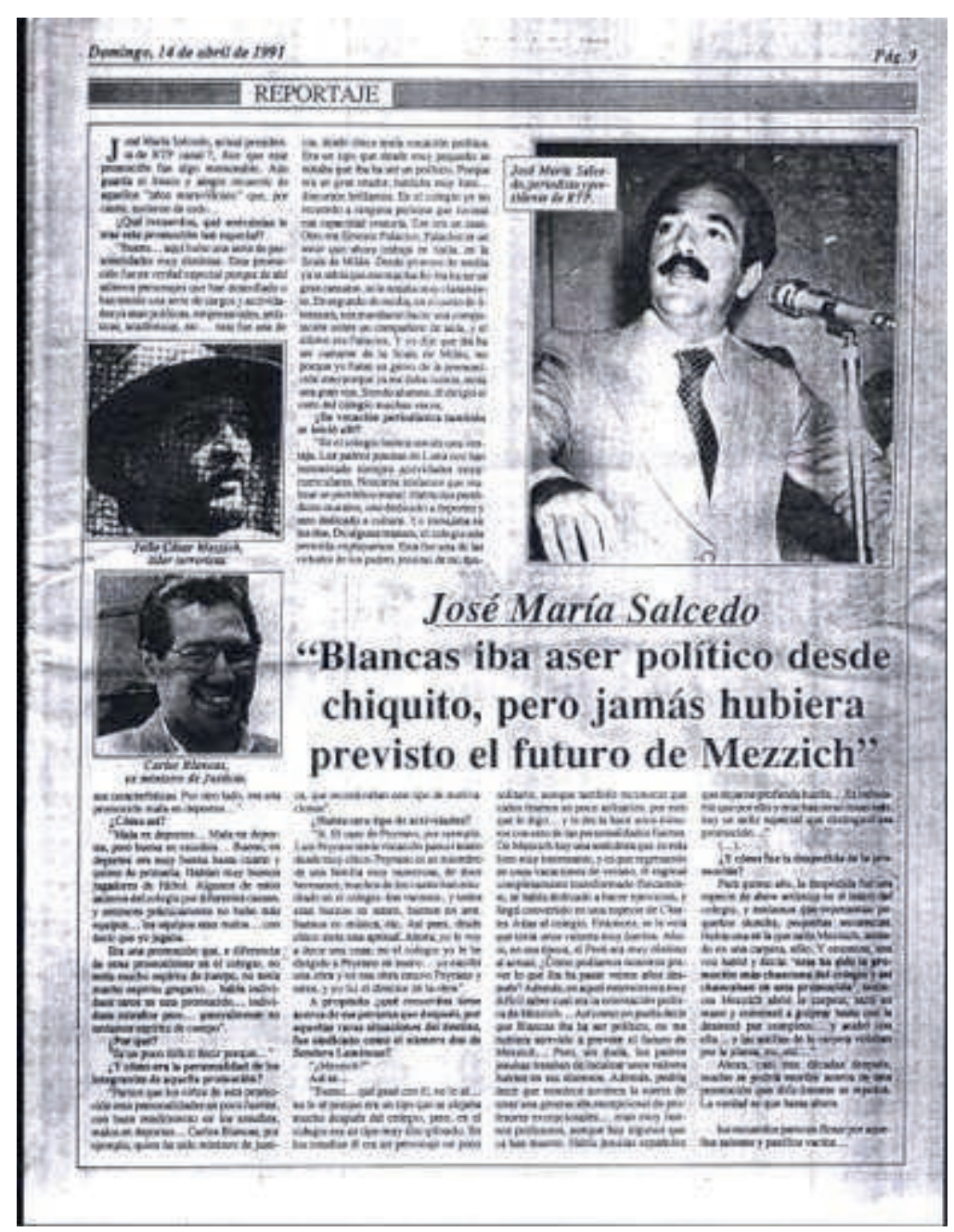

Figuras 12a. y 12b. Recortes de "!Qué buena promo...!"

\subsubsection{José María Salcedo: "Blancas iba a ser político desde chiquito, pero jamás hubiera previsto el futuro de Mezzich"}

(Entrevista grabada con grabadora portátil)

José María Salcedo, actual presidente de RTP (17 - 18) canal 7, dice que esta promoción fue algo memorable. Aún guarda el fresco y alegre recuerdo de aquellos "años maravillosos" que, por cierto, tuvieron de todo.

¿Qué recuerdos, qué anécdotas, le trae esta promoción tan especial? 
"Bueno... aquí hubo una serie de personalidades muy distintas. Esta promoción fue en verdad especial porque de allí salieron personajes que han desarrollado o han tenido una serie de cargos y actividades ya sean políticas, empresariales, artísticas, académicas, etc... Esta fue una de sus características. Por otro lado, era una promoción mala en deportes."

¿Cómo así?

"Mala en deportes... Mala en deportes, pero buena en estudios... Bueno, en deportes era muy buena hasta cuarto y quinto de primaria. Habían muy buenos jugadores de fútbol. Algunos de estos salieron del colegio por diferentes causas, y entonces prácticamente no hubo más equipos... los equipos eran malos... con decir que yo jugaba.

Era una promoción que, a diferencia de otras promociones en el colegio, no tenía mucho espíritu de cuerpo, no tenía mucho espíritu gregario... había individuos raros en esta promoción... individuos extraños, pero... generalmente no teníamos espíritu de cuerpo."

¿Por qué?

"Es un poco difícil decir porqué."

¿Y cómo era la personalidad de los integrantes de aquella promoción?

"Parece que los niños de esta promoción eran personalidades un poco fuertes, con buen rendimiento en los estudios, malos en deportes. Carlos Blancas, por ejemplo, quien ha sido ministro de justicia, desde chico tenía vocación política. Era un tipo que desde muy pequeño se notaba que iba a ser un político. Porque era un gran 
orador, hablaba muy bien... discursos brillantes. En el colegio yo no recuerdo a ninguna persona que tuviese esa capacidad oratoria. Ese era un caso. Otro era Ernesto Palacios. Palacios es un tenor que ahora trabaja en Italia, en la Scala de Milán. Desde primero de media ya se sabía que ese muchacho iba a ser un gran cantante, se le notaba muy claramente. En segundo de media, en el curso de literatura, nos mandaron hacer una composición sobre un compañero de aula, y el último era Palacios. Y yo dije que iba a ser cantante de la Scala de Milán. No porque yo fuese un genio de la premonición, sino porque ya me daba cuenta, tenía una gran voz. Siendo alumno, él dirigió el coro del colegio muchas veces."

¿Su vocación periodística también se inició allí?

"En el colegio hemos tenido una ventaja. Los padres jesuitas de Lima nos han incentivado siempre actividades extracurriculares. Nosotros teníamos que realizar un periódico mural. Había dos periódicos murales, uno dedicado a deportes y otro dedicado a cultura. Yo trabajaba en los dos. De alguna manera, el colegio nos permitía explayarnos. Esta fue una de las virtudes de los padres jesuitas de mi época, que incentivaban este tipo de motivaciones."

¿Había otro tipo de actividades?

"Sí. El caso de Peyrano, por ejemplo. Luis Peyrano tenía vocación para el teatro desde muy chico. Peyrano es un miembro de una familia muy numerosa, de doce hermanos, muchos de los cuales han estudiado en el colegio -los varones-, y todos eran buenos en teatro, buenos en arte, buenos en música, etc. Así, pues, desde chico tenía esta aptitud. Ahora, yo le voy a decir una cosa: en el colegio yo le he dirigido a Peyrano en teatro, ... yo escribí una obra y en esa obra estuvo Peyrano y otros, y yo fui el director de la obra." 
A propósito ¿qué recuerdos tiene acerca de esa persona que después, por aquellas raras situaciones del destino, fue sindicado como el número dos de Sendero Luminoso?

"¿Mezzich?"

Así es...

"Bueno... qué pasó con él, no lo sé... no lo sé porque era un tipo que se alejaba mucho después del colegio, pero, en el colegio era un tipo muy disciplinado. En los estudios él era un personaje un poco solitario, aunque también hay que reconocer que todos éramos un poco solitarios, por eso que le digo... y le decía hace unos minutos con esto de las personalidades fuertes. De Mezzich hay una anécdota que es más bien muy interesante, y es que regresando de unas vacaciones de verano, él regresó completamente transformado físicamente, se había dedicado a hacer ejercicios, y llegó convertido en una especie de Charles Atlas al colegio. Entonces, se le veía que tenía unos valores muy fuertes. Ahora, en esa época, el Perú era muy distinto al actual. ¿Cómo podíamos nosotros prever lo que iba a pasar veinte años después? Además, en aquel entonces era muy difícil saber cuál era la orientación política de Mezzich... Así como yo podía decir que Blancas iba a ser político, no me hubiera atrevido a prever en futuro de Mezzich... Pero, sin duda, los padres jesuitas trataban de inculcar unos valores fuertes en sus alumnos. Además, podríamos decir que nosotros tuvimos la suerte de tener una generación excepcional de profesores excepcionales... eran muy buenos profesores, aunque hay algunos que ya han muerto. Había jesuitas españoles que dejaron profunda huella... Es indudable que por ello y muchas otras cosas más, hay un sello especial que distinguió esa promoción..." 
¿Y cómo fue la despedida de la promoción?

"Para quinto año, la despedida fue una especie de show artístico en el teatro del colegio y teníamos que representar pequeños sketchs, pequeñas secuencias. Había una en la que salía Mezzich, sentado en una carpeta, sólo. Y entonces, una voz habló y decía: "Esta ha sido la promoción más chancona del colegio y así chancaban en esta promoción", entonces Mezzich abrió la carpeta, sacó un mazo y comenzó a golpear hasta que la destrozó por completo... y acabó con ella... y las astillas de la carpeta volaban por la platea, etc."

Ahora, casi tres décadas después, se podría escribir acerca de esta promoción que difícilmente se repetirá. La verdad es que hasta ahora los recuerdos parecen flotar por aquellos salones y pasillos vacíos.

\subsection{Miguel Hitotsuishi: Balada para un gentil hombre...}

(Crónica publicada en Suceso, revista dominical de Correo, el domingo 26 de enero de 1992, pp. 9)

\section{El "Chino" Miguel.}

Con ese cariñoso apodo lo llamábamos. Ayer 25 de enero se cumplió un año del fallecimiento de quien fuera tal vez uno de los mejores reporteros gráficos que han pasado por el periodismo peruano actual. Un verdadero maestro de la fotografía, creador de una escuela con estilo propio, admirado por propios y extraños.

Don Miguel era un personaje de mediana estatura, pelo oscuro y cejas pobladas. Sus gruesas gafas dejaban traslucir unos ojillos rasgados, de mirada pícara y traviesa con los que no paraba de buscar la siguiente "víctima" de sus bromas irresistibles. 
Tenía su escritorio a mi costado de la redacción del diario OJO, donde había un visor iluminado para ver los negativos y un sacapuntas convertido en un improvisado "recargador" de rollos fotográficos usados. Un curioso aparato inventado por él.

Nadie olvidará su alegría de vivir, aunque ya estaba enfermo. Jamás se le escuchó una queja, más bien las risas con que todos festejaban sus bromas.

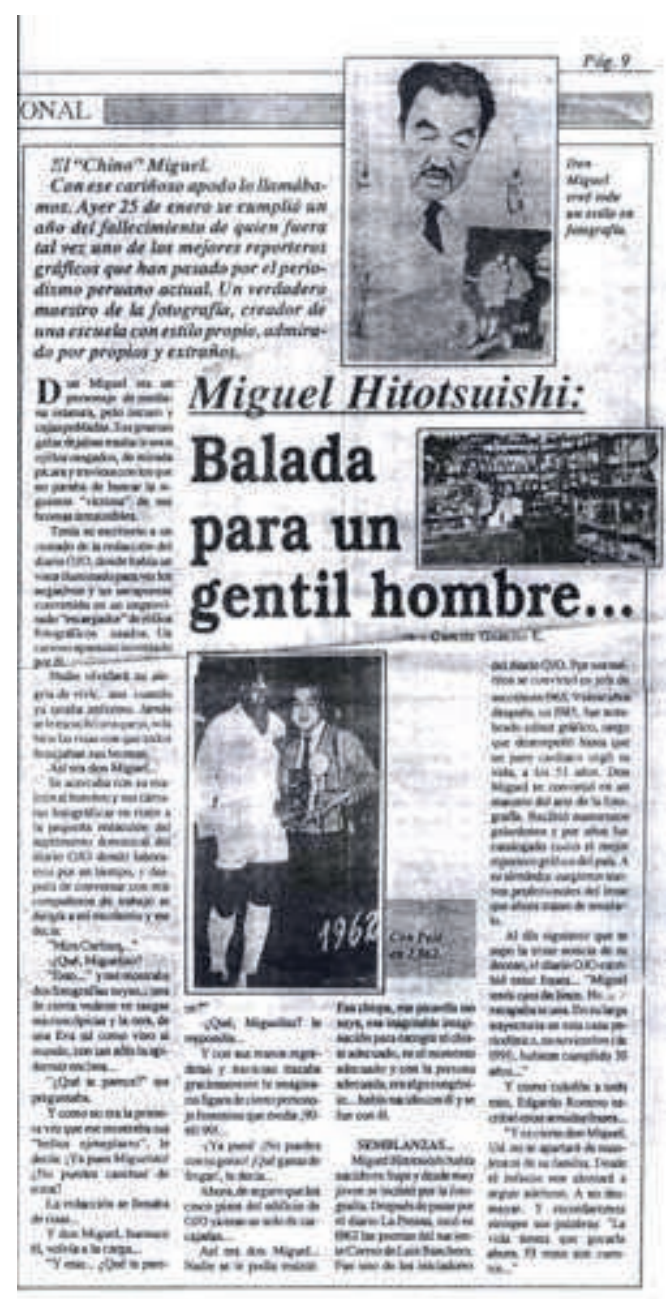

Figura 13. Recorte de "Miguel Hitotsuishi: balada para un gentil hombre".

Así era don Miguel...

Se acercaba, con su maletín al hombro y sus cámaras fotográficas en ristre, a la pequeña redacción del Suplemento Dominical del diario OJO, donde laboramos por 
un tiempo, y después de conversar con mis compañeros de trabajo se dirigía a mi escritorio y me decía:

- "Mira Carlitos"

- ¿Qué Miguelito?

- "Esto..."

Y me mostraba dos fotografías suyas... una de cierta vedette con tangas microscópicas y la otra, de una Eva tal como vino al mundo, con tan sólo la epidermis encima...

- "¿Qué te parece?"- Me preguntaba.

Y como no era la primera vez que me mostraba sus "bellos ejemplares", le decía:

- ¡Ya pues, Miguelito! ¿No puedes cambiar de tema?

La redacción se llenaba de risas.

Y don Miguel, buenazo él, volvía a la carga...

- "Y esto... ¿Qué te parece?"

- ¿Qué, Miguelito? Le respondía...

$\mathrm{Y}$ con sus manos regordetas y traviesas trazaba graciosamente la imaginaria figura de cierto personaje femenino que medía ¡90-60-90! 
- ¡Ya pues! ¡No puedes con tu genio! ¡Que ganas de fregar!-, le decía...

Ahora, de seguro que los cinco pisos del edificio de OJO eran un solo de carcajadas...

Así era don Miguel...

Nadie se le podía resistir. Esa chispa, esa picardía tan suya, esa inagotable imaginación para escoger el chiste adecuado, en el momento adecuado y con la persona adecuada, era algo congénito... había nacido con él y se fue con él.

\subsubsection{Semblanzas...}

Miguel Hitotsuishi había nacido en Supe y desde muy joven se inclinó por la fotografía. Después de pasar por el diario La Prensa, tocó en 1962 las puertas del naciente Correo de Luis Banchero. Fue uno de los iniciadores del diario OJO. Por sus méritos se convirtió en jefe de sección en 1965. Veinte años después, en 1985, fue nombrado editor gráfico, cargo que desempeñó hasta que un paro cardiaco cegó su vida, a los 53 años. Don Miguel se convirtió en un maestro del arte de la fotografía. Recibió numerosos galardones y por años fue catalogado como el mejor reportero gráfico del país. A su alrededor surgieron nuevos profesionales del lente que ahora tratan de emularlo.

$\mathrm{Al}$ día siguiente que se supo la triste noticia de su deceso, el diario OJO escribió estas frases... "Miguel tenía ojos de lince. No se le escapaba ni una. En su larga trayectoria en esta casa periodística, en noviembre (de 1991) hubiese cumplido 30 años..."

Y como colofón a todo esto, Edgardo Romero escribió estas sentidas frases... "Y es cierto don Miguel. Ud. no se apartará de nosotros ni de su familia. Desde el infinito 
nos alentará a seguir adelante. A no desmayar. Y recordaremos siempre sus palabras: La vida tienes que gozarla ahora. El resto son cuentos..."

\section{Notas Aclaratorias}

Nota: A la derecha de los hipervínculos se ha insertado la fecha de última apertura de la página Web citada.

1. Collao. Gran meseta o altiplano donde se asienta el lago Titicaca, el lago navegable más alto del mundo, ubicado entre Perú y Bolivia, a 3.816 metros sobre el nivel del mar.

2. Mamapacha. Madre Tierra, según la cosmovisión andina. Los incas la consideraban una diosa.

3. Manco Capac y Mama Ocllo. Leyenda citada por la investigadora estadounidense Simone Waisbard en su obra "Tiahuanaco, diez mil años de enigmas incas". (1)

4. Puno. Región o departamento del sur peruano, cuya capital es la ciudad del mismo nombre, ubicada a orillas del lago Titicaca.

5. Aymaras. Antiquísima etnia autóctona de los Andes del sur peruano, que también puebla los territorios de Bolivia, el norte de Argentina y una porción del norte chileno. En Perú, la lengua aymara es la tercera más importante, después del español y el quechua.

6. El lago sagrado de los incas, y también de los aymaras e infinidad de pueblos que han habitado sus orillas. 
7. Totora. Planta herbácea muy difundida no sólo en la región del Collao sino también en algunas zonas litorales del Pacífico peruano y ecuatoriano. Materia prima utilizada para la fabricación de las famosas balsas del lago Titicaca. Tanto el la región del Collao como en la costa norte del Perú estas embarcaciones reciben el nombre de "caballitos". En ambas regiones, la fabricación de estas balsas de totora configura una tradición antiquísima, de origen preincaico.

8. Los hermanos Ayar. Este mito, además de ser anterior al de Manco Cápac y Mama Ocllo, es, según los especialistas, más confiable por acercarse más al pensamiento andino. Sostiene que los hermanos Áyar fueron ocho -cuatro parejas- y que surgieron de una de las tres cavernas del cerro Tamputoco, situado inmediatamente al sur de Pacaritambo, cerca de la actual ciudad de Paruro. La caverna de la que salieron los Áyar era la Capactoco, que se hallaba entre las otras dos -Marastoco y Sutictoco-, de las que salieron los pueblos mara y tampu, respectivamente.

Las parejas que constituyeron los ocho hermanos Áyar fueron las siguientes:

- Áyar Manco y Mama Ocllo.

- Áyar Auca y Mama Huaco.

- Áyar Cachi y Mama Ipacura.

- Áyar Uchu y Mama Rahua.

Los Áyar, comandados por Áyar Manco y acompañados por diez ayllus -cinco hanan y cinco hurin-, partieron hacia el norte en busca de una tierra que fuera adecuada para cultivar y habitar, la cual sería identificada por ellos al hundirse en su suelo una barreta de oro. Pero, a poco de haber emprendido el camino, decidieron desprenderse de Áyar Cachi, motivados por la fortaleza y peligrosidad que había demostrado. Entonces, con engaños, lo encerraron para siempre en la caverna Capactoco. 
Después de un largo peregrinaje, que duró alrededor de 20 años y en el que acamparon en varios lugares, los hermanos Áyar arribaron al monte Huanacaure, en las proximidades y al sureste de la actual ciudad del Cusco. Los Áyar, dado lo apropiado del paraje, acordaron establecerse provisionalmente en él, y, para sacralizarlo y ligarlo permanente e indisolublemente a los incas, acordaron que Áyar Uchu se convirtiera en huaca. Así, este hermano se transformó en una huaca de piedra, que tomó el nombre de Huanacaure y se constituyó en el objeto central del culto allí prestado.

Los incas se dedicaron entonces a recorrer los alrededores en busca de la tierra feraz que constituía la finalidad de su peregrinación. En esta búsqueda exploraron terrenos cercanos a Colcabamba y llegaron hasta la campiña de Huaynapata, cerca del curacazgo de los saño y también del de los hualla. Este último, como hemos mencionado anteriormente, tenía por jefe a Apo Quiano y por sede el poblado de Pachatusan. En Huaynapata la barreta de oro arrojada por Áyar Manco -según algunos por Mama Huaco- se hundió plenamente, lo cual demostró la calidad cultivable de su suelo y provocó la decisión de los incas de apropiarse del lugar.

Poco después, mientras contemplaba desde la cima del monte Huanacaure el conjunto de Acamama, Áyar Manco, a quien el espíritu de Áyar Uchu le había comunicado que su padre, el Sol, había dispuesto tomara el nombre de Manco Cápac, le indicó a Áyar Auca, que gozaba de la facultad de volar, se trasladara donde actualmente se encuentra el Coricancha y se instalara en él. Cuando así lo hizo este último hermano, también se convirtió en piedra y tomó simbólicamente el lugar, lo que estimuló a Manco Cápac a emprender las acciones bélicas definitivas para apoderarse materialmente del Cusco. Extraído del sitio Web de la "Ciudad Inca del Cusco" (21) 
9. Según el diccionario Aymara de la Universidad Católica de Santiago de Chile, el vocablo Mallku es sinónimo de jefe o cacique. (22)

10. La sombra del eclipse total del 3 de noviembre de 1994 cubrió, precisamente, casi todo el sur peruano, parte de Brasil y el Atlántico Sur.

11. Valle del Cusco. Zona geográfica perteneciente a la región Cusco, Perú, cuya capital es la ciudad del mismo nombre (23).

12. La principal divinidad de la religión oficial del estado inca o Tahuantinsiyo. Véase "Dioses Wankas" (24).

13. Viracocha. El dios creador del mundo andino, divinidad muy respetada desde tiempos inmemoriales, cuyo culto fue adoptado también por los incas. Véase "Dioses Wankas" (24).

14. El vocablo Coricancha en lengua quechua o runa simi significa "Cerco o jardín de oro", y designa al principal templo del Cusco dedicado a las principales divinidades incas. Este maravilloso edificio sagrado era el verdadero centro neurálgico del Tahuantinsuyo; sobre sus restos los españoles edificaron la iglesia de Santo Domingo.

15. La gran plaza principal incaica del Cusco, hoy Plaza Mayor de esta ciudad.

16. Los intihuatanas eran monolitos o piedras erguidas, algunas muy hermosas, que los incas utilizaban como referencia para medir el paso de las horas del día, por lo que se les denominó con este término que significa "amarraderos del Sol" o "lugares donde se amarra al Sol". En otros términos se trababa de verdaderos relojes solares. A pesar de que muchos fueron destruidos durante el coloniaje por los llamados 
"extirpadores de idolatrías" españoles, algunos de estos "relojes solares" sobrevivieron como el de Machu Picchu, el "intihuatana" más conocido de todos.

17. Algunos cronistas de la Conquista del Perú señalan que hasta guerras eran detenidas por la incidencia de un eclipse.

18. Se trataba de la "Fiesta del Sol". La principal festividad religiosa de los incas. Se celebraba coincidiendo con el solsticio de invierno y marcaba el inicio de la temporada agrícola. Hoy se escenifica cada 24 de junio en la ciudad del Cusco para los turistas.

19. El Amaru. Este mito cuenta que cierta vez... Hubo una gran sequía, perecieron las plantas y desaparecieron hasta los líquenes y musgos bajo el sol implacable. La tierra se cuarteaba polvorienta, sin árboles que dieran sombra. La flor de qantu, la que florece en la aridez, sintió marchitase los pétalos. El capullo que quedaba intacto reacio a morir, fue transformando sus pétalos en alas y agitándose se desprendió de la planta calcinada convertido en colibrí. Se dirigió a la cordillera y llegó hasta la laguna de Wacracocha. Sin atreverse a beber ni sobrevolar sus aguas, las contempló y voló hacia la cumbre del Waitapallana. Se posó exhausto en la cima helada por el viento; con su último aliento suplicó ternura y piedad al padre Waitapallana, salvación para la sequía. Murió el colibrí.

Waitapallana se sintió acongojado por la tierra estéril y devastada, sentía el aroma de la flor de qantu que solía engalanar su atuendo y su fiesta. Tanto fue su dolor, que dos lágrimas de dura roca resbalaron hasta la superficie de Wacracocha y las aguas se abrieron haciendo retumbar al mundo. El estruendo y las lágrimas de Waitapallana llegaron al fondo del lago despertando al Amaru que dormita enroscado a lo largo de la cordillera con la cabeza justo en el lecho del lago. Se desperezaba, la tierra se movía con violencia; la laguna, agitada, dejó ver entre la 
espuma la cabeza del Amaru: serpiente alada con cabeza de llama y cola de pez, de ojos cristalinos y hocico rojizo.

El Amarú se elevó en el aire eclipsando el sol de ojos flameantes que estallan en ira. 10.000 guerreros con corazas y espuelas se lanzan a combatirlo. La lucha es feroz... del hocico del Amaru surge la niebla que va a parar a los cerros, del movimiento de sus alas se cae la lluvia en torrentes, de su cola de pez se desprende el granizo y de los reflejos dorados de las bellas escamas nace el arco iris. Así renace la vida cuando ya parecía extinguida, reverdece la tierra y se llenan de agua clara los puquiales.

En Perú creían que todo estaba escrito en las escamas del Amaru, las vidas, las cosas, las historias, las realidades y los sueños. $\left(^{*}\right)$

$\left(^{*}\right)$ Versión tomada del portal "Leyendas de Nuestra América":

http:/ / usuarios.lycos.es/ americalatina/lanim.htm\#amaru (16/12/04)

20. Bernabé Cobo. Jesuíta español nacido en Lopera (España) en 1582 y muerto en Lima (Perú) en 1657. Notable cronista, autor de "Historia General de las Indias" (1653), "Historia de la fundación de Lima" (1639), entre otros.

21. Runas. La gente, las personas. Los habitantes del imperio de los incas.

22. Pututo. Instrumento musical de viento fabricado a base de la concha de caracoles marinos, típico de las zonas andinas y de un sonido lánguido y penetrante.

23. Huancavilca, pueblo autóctono de las provincias de Guayas y Manabi (Ecuador); esta etnia compartió con los manteños (Manta) y punae (Isla de Puna); el activo comercio con las rojas conchas del Spondylus se desarrollaba a partir de estas 
regiones, donde se encontraban -y se encuentran aún- los mayores yacimientos de la concha sagrada.

24. Mullu, Spondylus. Sus rastros han sido encontrados desde las culturas centroamericanas y México hasta el sur de Chile y Argentina. (26)

25. El Niño es una contracorriente marina que suele bajar cíclicamente desde las costas ecuatoriales del Pacífico hacía el sur, bordeando los litorales de Ecuador y Perú. Se trata de unas aguas calientes que alteran la corriente de Humboldt o "Corriente Peruana", de aguas frías. Recibe este nombre porque suele manifestarse a fines de diciembre, coincidiendo con la Navidad. Su a veces errático comportamiento ha provocado verdaderos desastres globales, como los devastadores Niños de 198283 y el de 1997-98 (25). Se dice que esta anomalía climática fue causante del declive de civilizaciones como los mochica y chumú, grandes culturas del norte peruano.

26. El santuario religioso más importante de la costa peruana, aún después de la Conquista, donde afluían miles de peregrinos para venerar el dios creador Pachacamac, cuyo ídolo se encontraba en el interior de un cuartucho en la cima de una pirámide, el mismo que siglos después apareció tirado en un basural y hoy forma parte de la colección del Museo de Sitio local. Los incas, lejos de destruir este lugar sagrado, construyeron en él sus propios templos. Ver sitio Web del Museo de Sitio de Pachacamac:

http:// pachacamac.perucultural.org.pe/santu.htm (13/12/04)

27. En algunas iconografías del antiguo México se puede observar al dios Tlaloc llevando una concha de Spondylus entre las manos. (8)

28. Ver: Spondylus, Strombus y Conus: Ofrendas a los dioses andino (26). 
29. Este comercio es atestiguado por los primeros españoles que llegaron a las costas de Ecuador y el norte del Perú.

30. Tambos. Construcciones que servían de refugio y avituallamiento para los caminantes en la vasta red de caminos del imperio inca. Algunos eran muy grandes, conformando verdaderos centros poblados, otros, simplemente lugares de intercambio de postas para los chasquis, los mensajeros incas.

31. Callejón de Huaylas. Ancho valle de los Andes Centrales peruanos formado por el río Santa, que discurre entre la Cordillera Blanca (nevada) y la Negra (sin nieves); el Santa corre de sur a norte y termina desembocando en el Océano Pacífico, cerca del puerto de Chimbote. Llega al mar después de romper la cordillera Occidental (Negra) formando el famoso Cañón del Pato. A sus orillas se encuentran bellas ciudades como Huaraz, la capital de la Región Ancash, además de Carhuaz, Caraz, Recuay y otras. Este valle, conocido como "la Suiza peruana", es un gran destino para el turismo de aventura.

32. Huascarán. Es el nevado más alto del Perú, con 6.767 metros sobre el nivel del mar. Por sus dos enormes "gibas" también es llamado "el camello blanco de los Andes". Hoy presenta en su pico norte una enorme "herida": el lugar desde donde se desprendió la masa de rocas, hielo y barro que arrasó con Yungay tras el terremoto del 31 de mayo de 1970.

33. Pequeño afluente del Santa, escenario de una batalla que le dio nombre a esta región (29).

34. Ichu. Planta herbácea típica de las zonas alto andinas, que tapiza llanuras y cerros en las "punas", pisos ecológicos situados por encima de los 3.400 metros de altura. 
35. Chan-Chan (Perú). Centro urbano prehispánico considerada la ciudad de barro más grande del mundo. Ubicada a unos cuatro kilómetros al norte de la ciudad de Trujillo, fue la capital política y religiosa del reino Chimú, un poderoso estado indígena que rivalizó con los incas.

36. Algunas ilustraciones de Martínez de Compañón, obispo español del siglo XVII radicado en Trujillo, por su diseño, trazo y colorido, que parecen recordar al estilo de los azulejos sevillanos, podrían ser una pista documental, aunque los textos escritos de este autor están en condición de "no habidos" hasta la fecha.

37. La pantorrilla y el copete. Dícese de una moda aburguesada que imperó en la sociedad urbana de las grandes ciudades costeras en el Perú de los siglos XVII, XVIII y parte del XIX, sobre todo en Lima y Trujillo. Por aquella época, ciertas prendas de vestir, como los pantalones abotonados que llegaban hasta los muslos, que usaban los caballeros, y el copete femenino, eran sinónimos de distinción, propio de la gente adinerada.

38. Le dicen "La capital de la primavera" por su famoso "Festival Internacional de Primavera", gran evento cultural turístico que incluye un vistoso corso callejero que atrae a muchos visitantes. Se celebra en la última semana de septiembre, coincidiendo con el inicio de la primavera (30).

39. Camposanto recientemente declarado patrimonio cultural peruano y museo de la escultura funeraria en Lima.

http:/ / www.terra.com.pe/sophia/presbitero/pescultu2.shtml (13/12/04)

40. ¡Ya no ya! Exclamación admirativa propia del habla popular peruana, tan enorme como el insufrible laberinto de los Museos Vaticanos... 
41. El baile de "Zorba, el griego". Por aquellas fechas se mostró un video en el que aparecía el cabecilla senderista divirtiéndose junto con sus secuaces, en tomas realizadas durante una de sus reuniones sociales. En una parte de esta cinta se escucha la música de la famosa película "Zorba, el griego", y se puede apreciar cómo Guzmán se levanta de su asiento para bailar. Este hecho causó conmoción pues desde hacía un tiempo se decía que Abimael Guzmán, el "camarada Gonzalo", había muerto.

42. Fue en estas circunstancias donde se habló de la "dipsomanía" de Abimael Guzmán, es decir, una irresistible tendencia a beber alcohol. La palabra tiene su origen en el idioma griego: dípsa, sed, y manía, locura.

43. Ayacucho. Capital de la provincia de Huamanga y de la región del mismo nombre, es una de las ciudades más bellas y agradables del Perú, cuenta con muchos atractivos turísticos. Iglesias y casonas Coloniales, restos arqueológicos que revelan su pasado histórico cuentan entre sus atractivos turísticos. Durante las dos décadas pasadas, esta ciudad fue el germen de la violencia terrorista en el Perú. Su nombre en quechua significa, paradójicamente, "rincón de muertos" (31).

44. Morote, padre. El hijo de este, Osmán Morote, es considerado como el segundo en la jerarquía organizativa de Sendero Luminoso. Hoy purga cadena perpetua.

45. Nada que ver, por cierto, con los "Tupamaros" (32), una organización clandestina uruguaya surgida entre los años sesenta y setenta. Su nombre es el resultado de un juego de palabras derivado de Tupac Amaru II (33), apodo con el que era conocido José Gabriel Condorcanqui, cacique de Tinta (Cusco), quien en el siglo XVIII lideró en el sur peruano la mayor revuelta popular contra la dominación española jamás vista desde la Conquista del Perú. Su figura inspiró, de mala forma, alguna que otra seudo ideología política, de claro tinte reivindicacionista, y, desafortunadamente, no 
faltaron las que promovían el terrorismo subversivo, aunque, en un principio, esto fue algo ajeno al Perú.

46. Este controvertido video no sólo desmitificó la condición, por ese entonces, casi mítica de la existencia del genocida Abimael Guzmán -a quién sus seguidores hicieron creer que había muerto-, sino que, además, reveló algunas de sus humanas debilidades (34).

47. Casi un año después de la publicación de este reportaje, en septiembre de 1992, un cuerpo de la Policía Nacional del Perú puso a este delincuente terrorista y a sus secuaces tras las rejas, después de haber liderado una guerra interna que dejó 70 mil muertos entre 1980 y 1992 (35).

\section{Referencias y fuentes}

(Nota: A la derecha de los hipervínculos se ha insertado la fecha de última apertura de la página Web citada)

1. "Tiahuanaco, diez mil años de enigmas incas". Simone Waisbard. Editorial Diana, México, 1975

2. Op. Cit.

3. Leyenda de Manco Capac y Mama Ocllo. "El Origen de la civilización" http:/ / usuarios.lycos.es/ americalatina/lcivi.htm\#manco (14/12/04)

4. Aspero. Museo de Arqueología y Antropología de la Universidad Nacional Mayor de San Marcos.

http:/ / museoarqueologiasanmarcos.perucultural.org.pe/etep27.htm (14/12/04) 
5. La Galgada. Museo de Arqueología y Antropología de la Universidad Nacional Mayor de San Marcos.

http:/ / museoarqueologiasanmarcos.perucultural.org.pe/etep27.htm (14/12/04)

6. The University of Texas at Austin.

http://www.utexas.edu/ (16/12/04)

7. Museo de Arqueología y Antropología de la Universidad Nacional Mayor de San Marcos.

http:/ / museoarqueologiasanmarcos.perucultural.org.pe/etep27.htm (14/12/04)

8. "Las conchas del género Spondylus en el México antiguo".

http://www.ibiologia.unam.mx/barra/congresos/pdf/malacologia/extras/belem_ zuniga.pdf (14/12/04)

9. Isla de La Plata (sitio Web en alemán)

http:/ / www.yaqupacha.de/ deakt99d.htm (14/12/04)

10. "Fortaleciendo la paz Perú - Ecuador".

http:/ / www.cipca.org.pe/cipca/frontera/Reg-Naci\%F3n.htm (14/12/04)

11. Municipalidad Provincial de Trujillo: Monumentos.

http:/ / www.munitrujillo.gob.pe/Trujillo/AtractivosTuristicos/paginas/

CentroHist\%F3rico_ArquitecturaCivil.htm (15/12/04)

12. Azulejos sevillanos. Siglo XVIII

http:/ / www.arrakis.es/ ramoscor/sigloxviii.html (15/12/04)

13. Op. Cit. (11) 
14. La Guerra del Pacífico.

http://members.tripod.com/ Guerra_del_Pacifico/guerra_pac.html (14/12/04)

15. Sin referencias.

16. Capilla Sixtina.

http://vaticano.s5.com/capilla.htm (14/12/04)

17. Televisión Nacional del Perú TNP

http://www.tnp.com.pe/

18. "La tv no me quita el sueño". José María Salcedo.

http:// www.caretas.com.pe/1999/1571/cine/ cine.htm (14/12/04)

19. Puno.

http://www.gruponuevomundo.com.pe/funcionalidades/esp/informacion/puno.h $\operatorname{tm}(11 / 12 / 04)$

20. Scirpus totora.

http://www.agualtiplano.net/biodiversidad/plantas/13_prin.htm (11/12/04)

21. Los hermanos Ayar.

http:// ciudadinca.perucultural.org.pe/fundacion2.htm (11/12/04)

22. "Diccionario Aymara de la Universidad Católica de Santiago de Chile."

http://www.uc.cl/related/atees/chile/atees_hele/contenidos/glosario/aymara.do c $(15 / 12 / 04)$

23. "Dioses Wankas" 
http://www.huancainos.com/dioses.htm (14/12/04)

24. "Dioses Wankas"

Idem. (23)

25. El Niño.

http://www.naylamp.dhn.mil.pe/nino/mainFrame.htm (11/12/04)

26. "Spondylus, Strombus y Conus: Ofrendas a los dioses andinos".

http://manandmollusc.net/peru_spanish.html (10/12/04)

27. "La navegación indígena".

http://www.fuerzasarmadasecuador.org/espanol/historia/reinoquitonavegacion.h $\operatorname{tm}(16 / 12 / 04)$

28. Información obtenida de la "Enciclopedia Universal Ilustrada EuropeoAmericana", tomo 43, Espasa Calpe Editores, Madrid, 1958

29. Gobierno Regional de Ancash.

http:/ / 200.37.228.133/index2.htm (11/12/04)

30. "Festival Internacional de Primavera". Trujillo, Perú.

http:/ / www.festivaldeprimavera.org.pe/ main.htm (13/12/04)

31. Huamanga (Ayacucho)

http://www.ayacuchoperu.com/

32. MLN Tupamaros.

http://www.chasque.net/mlnweb/ (16/12/04) 
33. Información sobre Tupac Amaru II

http:/ / www.eden.rutgers.edu/ sdarroch/ (16/12/04)

34. "Guzmán bailando".

http:/ / www.terra.com.pe/noticias/nacional/15/15895.html (16/12/04)

35. "La captura bajo una nueva luz".

http:/ / www.caretas.com.pe/1998/1533/captura/captura.htm

36. Promoción San Luis Gonzaga (1963)

http:// www.ci.edu.pe/asia/ASIA/1963.htm

\section{Procedencia de las imágenes}

1. Artículo publicado en el Suplemento Dominical del diario OJO, el domingo 7 de junio de 1987, pp. 6

2. Artículo publicado en el Suplemento Dominical del diario OJO, el domingo 07 de agosto de 1994, pp. 10

3a. Reportaje publicado en el Suplemento Dominical de OJO, el domingo 23 de mayo de 1999, pp. $10-11$

3b. Idem.

4. Artículo publicado en el Suplemento Dominical de OJO, el domingo 01 de agosto de 1993, pp. 10

5. Crónica publicada en el Suplemento Dominical de OJO, el domingo 24 de mayo de 1987, pp. 7 
6a. Reportaje publicado en el Suplemento Dominical del diario OJO, el domingo 13 de mayo de 1990, pp. 12 - 13 - Con texto y fotos del autor.

6b. Idem.

7. Artículo publicado en el Suplemento Dominical de OJO, el domingo 9 de julio de 1989, pp. 10

8a. Reportaje publicado en el Suplemento Dominical de OJO, el domingo 22 de marzo de 1998, pp. $10-11$

8b. Idem.

9. Crónica publicada en el Suplemento Dominical de OJO, el domingo 26 de marzo de 1988, pp. 5)

10. Crónica publicada en el diario Correo de Lima, el 14 de marzo de 1974, pp. 11

11. Reportaje y entrevista publicada en Suceso, revista dominical del diario Correo, el domingo 24 de febrero de 1991, pp. 8

12a. Reportaje publicado en Suceso, revista dominical del diario Correo, el domingo 14 de abril de 1991, pp. 8 - 9

12b. Idem.

13. Crónica publicada en Suceso, revista dominical de Correo, el domingo 26 de enero de 1992, pp. 9 